\title{
Endothelial Barrier Function and Leukocyte Transmigration in Atherosclerosis
}

\author{
Thijs J. Sluiter ${ }^{1,2}{ }^{\mathbb{D}}$, Jaap D. van Buul ${ }^{3} \mathbb{D}$, Stephan Huveneers ${ }^{4}$, Paul H. A. Quax ${ }^{1,2} \mathbb{D}^{\mathbb{D}}$ and \\ Margreet R. de Vries $1,2, * \mathbb{D}$
}

1 Department of Vascular Surgery, Leiden University Medical Center, 2333 ZA Leiden, The Netherlands; t.j.sluiter@lumc.nl (T.J.S.); p.h.a.quax@lumc.nl (P.H.A.Q.)

2 Einthoven Laboratory for Experimental Vascular Medicine, Leiden University Medical Center, 2333 ZA Leiden, The Netherlands

3 Sanquin Research and Landsteiner Laboratory, Leeuwenhoek Centre for Advanced Microscopy, Swammerdam Institute for Life Sciences, University of Amsterdam, 1066 CX Amsterdam, The Netherlands; j.vanbuul@sanquin.nl

4 Department of Medical Biochemistry, Amsterdam Cardiovascular Sciences, Amsterdam University Medical Center, Location AMC, University of Amsterdam, 1105 AZ Amsterdam, The Netherlands; s.huveneers@amsterdamumc.nl

* Correspondence: m.r.de_vries@lumc.nl; Tel.: +31-(71)-526-5147

Citation: Sluiter, T.J.; van Buul, J.D.; Huveneers, S.; Quax, P.H.A.; de Vries, M.R. Endothelial Barrier Function and Leukocyte Transmigration in Atherosclerosis. Biomedicines 2021, 9, 328. https://doi.org/10.3390/ biomedicines 9040328

Academic Editor: Nadia Alfaidy

Received: 14 February 2021

Accepted: 19 March 2021

Published: 24 March 2021

Publisher's Note: MDPI stays neutral with regard to jurisdictional claims in published maps and institutional affiliations.

Copyright: (c) 2021 by the authors. Licensee MDPI, Basel, Switzerland. This article is an open access article distributed under the terms and conditions of the Creative Commons Attribution (CC BY) license (https:// creativecommons.org/licenses/by/ $4.0 /)$.
Abstract: The vascular endothelium is a highly specialized barrier that controls passage of fluids and migration of cells from the lumen into the vessel wall. Endothelial cells assist leukocytes to extravasate and despite the variety in the specific mechanisms utilized by different leukocytes to cross different vascular beds, there is a general principle of capture, rolling, slow rolling, arrest, crawling, and ultimately diapedesis via a paracellular or transcellular route. In atherosclerosis, the barrier function of the endothelium is impaired leading to uncontrolled leukocyte extravasation and vascular leakage. This is also observed in the neovessels that grow into the atherosclerotic plaque leading to intraplaque hemorrhage and plaque destabilization. This review focuses on the vascular endothelial barrier function and the interaction between endothelial cells and leukocytes during transmigration. We will discuss the role of endothelial dysfunction, transendothelial migration of leukocytes and plaque angiogenesis in atherosclerosis.

Keywords: endothelial barrier; endothelial cell junctions; endothelial dysfunction; inflammation; leukocyte transmigration; atherosclerosis; intraplaque-angiogenesis

\section{Introduction}

The vascular endothelial lining is highly specialized and acts as a semi-confluent barrier controlling passage of fluids and migration of leukocytes from the lumen into the vessel wall. Under inflammatory conditions, endothelial cells (ECs) can assist leukocytes to leave the circulation to migrate into the underlying tissue to fight invading pathogens [1,2]. Under pathophysiologic conditions, such as chronic inflammation and atherosclerosis, ECs are activated and the barrier function of the endothelium becomes impaired, leading to uncontrolled leukocyte migration and vascular leakage [3,4]. Atherosclerosis starts with EC activation mainly due to lipid mediators such as oxidized low density lipoprotein (ox-LDL), which upregulates the expression of endothelial adhesion receptors such as intercellular adhesion molecule-1 (ICAM-1) and vascular adhesion molecule-1 (VCAM-1). Consequently, immune cells enter the subendothelial tissue initiating plaque formation. At later stages of plaque development, immune cells can also enter the plaque through vessels growing into the plaque $[5,6]$. These plaque neovessels are often immature with a limited barrier function [7] leading to increased immune cell transmigration and intraplaque hemorrhage. This results in plaque instability, ultimately leading to rupture and the progression of 
cardiovascular diseases, such as stroke, myocardial infarction (MI), or peripheral artery disease (PAD).

This review summarizes current knowledge on how the endothelium forms a semipermeable barrier and how the endothelium assists the immune cells in their journey into the underlying tissue. We will discuss the role of endothelial dysfunction in plaque angiogenesis and its contribution to the development of atherosclerosis in different vascular beds.

\section{The Endothelial Barrier Function}

The vascular endothelium lines the inner layer of the blood vessel and actively controls extravasation of fluids, ions, molecules, and leukocytes [8]. The integrity of the endothelium is maintained by intercellular junctions to prevent vascular leakage [9]. These cell-cell junctions consist of protein complexes that are part of the adherens junctions (AJs), gap junctions (GJs), tight junctions (TJs), and additional other adhesion receptors such as CD31/Platelet Endothelial Cell Adhesion Molecule-1 (PECAM-1), which can be disrupted during EC activation (Figure 1). GJs are formed by connexin-mediated transmembrane channels allowing direct communication between ECs via the passage of ions and small signaling molecules [10]. In contrast, AJs and TJs form adhesion structures that control paracellular permeability [8]. The organization of such EC junctions varies within the vascular tree depending on the tissue-specific function of the endothelium [11,12].

\subsection{Tight Junctions}

TJs control permeability of ions and small molecules and are most prominent in the blood-brain barrier (BBB) and the inner blood-retinal barrier where permeability is restricted [13]. TJs are mainly comprised of the receptors occludin, claudins and junctional adhesion molecules (JAMs) [14]. Claudin-5 is crucial for maintaining BBB-integrity in mice [15]. Adhesion molecules contribute to endothelial integrity through interaction with neighboring cells and induction of intracellular signaling, via their cytoplasmic domains and their extracellular domain [16]. TJ-proteins are linked to the actin cytoskeleton via the adaptor proteins Zonula Occludens (ZO) 1, 2, and 3 as well as other protein complexes [17]. Interestingly, bidirectional signaling has been found between ZO-1 and JAM-A. This regulates junctional localization of both molecules suggesting their involvement in upstream regulation of TJ assembly [18]. In addition, the assembly of TJs is dependent on formation of AJs [19] and changes in TJs are coordinated with changes in AJs [20].

\subsection{Adherens Junctions}

AJs are cadherin-based adhesions that provide mechanical strength to cell-cell junctions. Vascular Endothelial (VE)-cadherin has extracellular binding domains and a cytoplasmic domain that is connected to the actin cytoskeleton through interaction with catenins. VE-cadherin, together with PECAM-1-based adhesions, provides mechanical strength to the endothelial junctions [21,22]. Intracellularly, p120-catenin binds to the membrane-proximal cytoplasmic domain of VE-cadherin and promotes cadherin clustering by reducing turnover, whereas $\beta / \gamma$-catenins bind to the membrane-distal cytoplasmic domain, recruiting $\alpha$-catenin which binds actin filaments and is therefore crucial for AJ stabilization [23,24]. Mice with a genetically engineered VE-cadherin- $\alpha$-catenin fusion construct, unable to dynamically mediate this interaction, were resistant to vascular endothelial growth factor (VEGF)- and histamine-induced vascular leakage [25]. VE-cadherin promotes the formation of functional TJs through upregulation of claudin-5 [20], whereas the tight junction molecule JAM-C decreases endothelial integrity by targeting VE-cadherin, highlighting the complexity of the interplay between different junctional proteins [26]. The adhesion of VE-cadherin is controlled by phosphorylation and dephosphorylation on specific tyrosine residues [27]. In response to vascular permeability stimulators, such as VEGF and bradykinin, the tyrosine residues of VE-cadherin become phosphorylated (Y685 and Y658), resulting in instable AJs and an increased vascular permeability [28]. Interestingly, dephosphorylation of Y731 of VE-cadherin results in increased leukocyte 
transmigration $[29,30]$. It is important to note that leukocyte transendothelial migration (TEM) and vascular permeability are in fact uncoupled processes. During leukocyte TEM, vascular leakage is limited by a specialized endothelial-originated F-actin ring that acts as elastic strap surrounding the penetrating leukocyte [4].
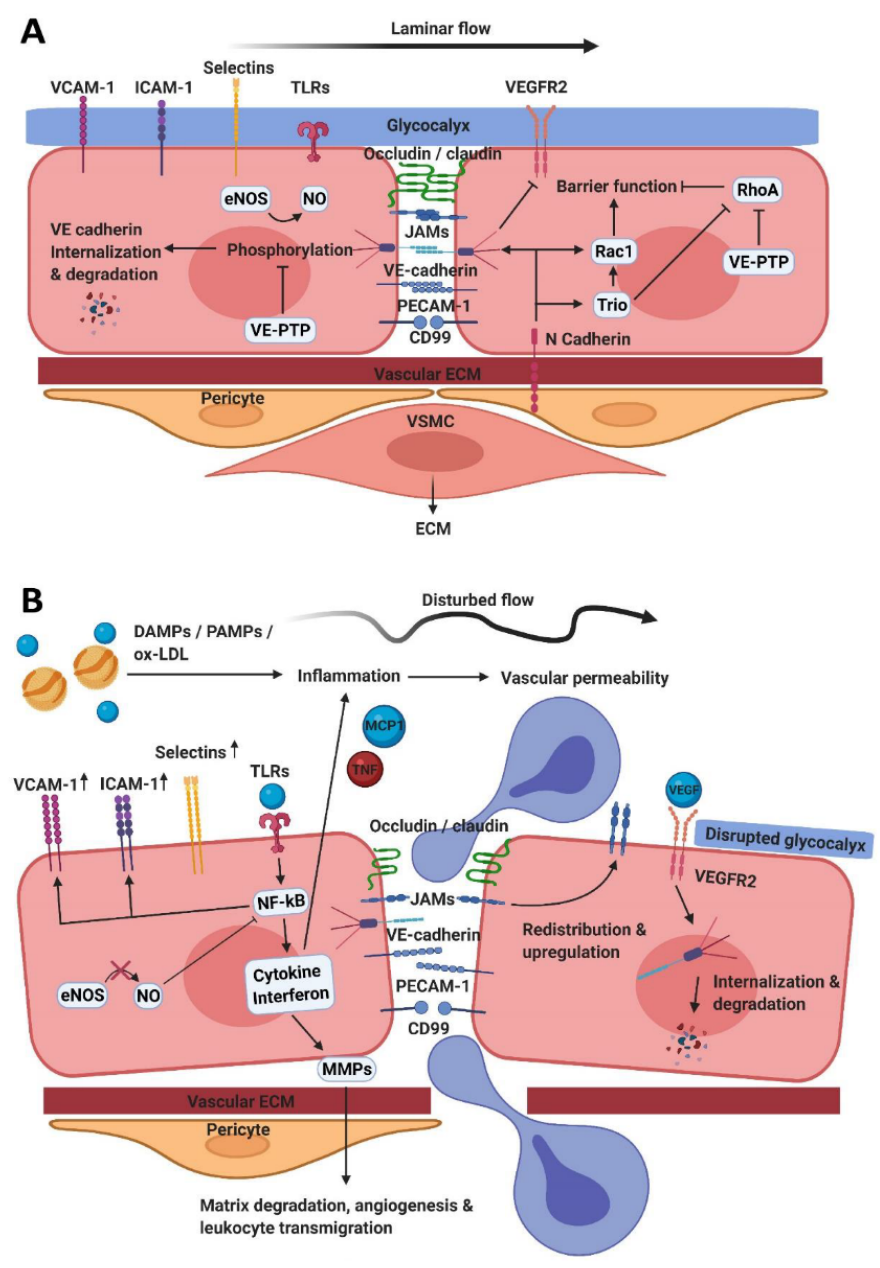

Figure 1. The endothelium under (patho)physiologic conditions. (A) Tight junctions, made by occludins, claudins, and JAMs, together with adherens junctions, formed by VE-cadherin, PECAM-1 and CD99 control endothelial barrier function by maintaining interendothelial junctions. Endothelial cells are connected to the vascular ECM, pericytes and VSMCs via N-cadherin and other interactions. $\mathrm{N}$-cadherin activates Trio, Rac1 and also directly induces assembly of VE-cadherin junctions. Trio, as well as VE-PTP, inhibits RhoA. Additionally, VE-PTP prevents phosphorylation and subsequently degradation of VE-cadherin. NO is formed aiming to maintain a laminar flow together with the functional and intact glycocalyx. (B) Endothelial cells can become activated by disturbed flow and inflammatory mediators. VEGF activates VEGFR2 leading to internalization and degradation of VE-cadherin and TLR-activation results in NF-KB-activation. This mediates upregulation of adhesion molecules and cytokine/interferon production. This ultimately leads to leukocyte transmigration, vascular permeability, matrix degradation and angiogenesis. AJs-adherens junctions; DAMPsdamage associated molecular patterns; ECs—endothelial cells; ECM—extracellular matrix; eNOSendothelial nitric oxide; ICAM-1—intracellular adhesion molecule-1; JAMs-junctional adhesion molecules; MMPs—matrix metallo proteinases; NO—nitric oxide; ox-LDL—oxidized low-density lipoproteins; PAMPs—pathogen-associated molecular patterns; PECAM-1—platelet endothelial cell adhesion molecule-1; TJs — tight junctions; TLR - Toll-like receptor; VCAM-1—vascular adhesion molecule-1; VE-cadherin-vascular endothelial-cadherin; VEGF-vascular endothelial growth factor; VEGFR2-VEGF receptor 2; VE-PTP — vascular endothelial protein tyrosine phosphatase; VSMCsvascular smooth muscle cells. 
One way of regulating the phosphorylation status of VE-cadherin is through the interaction with vascular endothelial protein tyrosine phosphatase (VE-PTP). VE-PTP binds through its extracellular domain to VE-cadherin and reduces tyrosine phosphorylation of VE-cadherin. This promotes the adhesive function of VE-cadherin by reducing its internalization independently of the phosphatase activity of VE-PTP. Thus, VE-PTP promotes the endothelial barrier and reduces vascular permeability [31,32]. VE-PTP can also influence Rho GTPase activity at AJs [32]. The family of Rho GTPases (e.g., RhoA) is crucial for the regulation of the endothelial barrier function as well as angiogenesis, as they control EC adhesion structures through cytoskeletal remodeling [33]. Rho GTPases are activated by guanine-nucleotide exchange factors (GEFs) and have different functions varying from improving cell-cell junction stability to mediating cell migration. VE-PTP inhibits binding of RhoGEF GEF-H1 to the small GTPase RhoA and decreases RhoA activity at AJs. As a consequence, local tension is lost resulting in more stable junctions and improved barrier function [32]. Trio, another RhoGEF, can bind to VE-cadherin during junction (re-)formation, and locally activate the small GTPase Rac1. Increased Rac1 activity at junction regions promotes the stabilization of VE-cadherin-based adhesions and thereby increasing the barrier function [34].

Another important endothelial cell-cell junction protein is PECAM-1. PECAM-1 is a transmembrane glycoprotein expressed on ECs, platelets, and several leukocytesubsets [35]. Intracellular signaling occurs via phosphorylation of Ig-like immunoreceptor tyrosine-based inhibition motifs resulting in recruitment of Src Homology 2 phosphatases and interfering with tyrosine kinase pathways [36]. This affects various intracellular signaling molecules and pathways such as ICAM-1, interleukin (IL)-1 $\beta$ signaling, thereby affecting processes such as cell survival, shear stress and barrier integrity [37]. PECAM-1 can also promote endothelial junction stability through dephosphorylation of $\beta$-catenin [38]. It was found that ECs expressing PECAM-1 exhibited improved steady-state barrier function and more rapidly restored barrier integrity following perturbation, compared to PECAM-1 deficient ECs [35]. PECAM-1, together with VE-cadherin and VEGF receptor 2 (VEGFR2) forms a mechanosensory complex controlling responsiveness to flow [39]. The function of PECAM-1 in flow can impact downstream NF- $\kappa$ B activation, integrins, small GTPase RhoA signaling, actin polymerization, and thus the formation of stress fibers $[39,40]$. PECAM-1 ${ }^{-/-}$mice cannot activate NF- $\kappa B$ and downstream inflammatory genes in regions of disturbed flow [39].

\subsection{Tissue-Specific Endothelium}

Depending on the anatomical locations within the vascular tree, the endothelium can be relatively leaky (capillaries/venules) or not (arteries). In addition, depending on the organ-specific function of the endothelium, it can be continuous (e.g., brain) or fenestrated (e.g., kidney/glands), allowing for more or less extravasation respectively, depending on TJs and AJs [41,42]. Transit through fenestrated endothelium is limited to micro-molecules only and is controlled by e.g., blood flow, the basement membrane and glycocalyx [41]. The glycocalyx is a highly charged layer coving the luminal side of the endothelium functioning as a vascular barrier as well as a mechanotransducer regulating vascular tone [43]. The basal side of ECs is connected to the basement membrane, rich in laminin and type IV collagen, which strengthen the endothelium and can control extravasation of fluids in, e.g., the BBB [44]. In addition to paracellular permeability, ECs control transcellular transport of (macro)molecules such as lipoproteins.

Capillaries are also surrounded by pericytes which are multipotent perivascular cells. The EC-pericyte interaction is important to regulate EC proliferation, vessel tone and endothelial barrier function. Loss of pericyte coverage on the vascular endothelium is associated with excessive angiogenesis and BBB disruption, leading to increased plasma leakage $[45,46]$. Signaling between pericytes and ECs can occur through $\mathrm{N}$-cadherin, which forms heterotypic adhesions between ECs and surrounding cells such as pericytes and VSMC and involves Trio signaling [47]. In addition, this intercellular communication also 
occurs via paracrine secretion of growth factors, such as VEGF, which increase leukocyte transmigration and angiogenesis [48].

The interstitial extracellular matrix (ECM), together with the basement membrane, forms the vascular ECM giving the endothelium structural and mechanical strength, necessary to resist hemodynamic forces on the vessel wall [49]. The endothelium also interacts with the vascular ECM. Collagens and fibronectin are the major components of the vascular ECM, in which also vascular smooth muscle cells (VSMCs) are embedded. ECM components can modulate the phenotype of vascular cells. During angiogenesis, ECs interact with type I collagen, resulting in upregulation of P-selectin and monocyte chemoattractant protein-1 (MCP-1) via ERK1/2 dependent mechanisms, which contribute to enhanced leukocyte attachment [50]. VSMCs contribute to the endothelial barrier function by providing resistance to mechanical stress, partly by synthesizing ECM, as well as regulating vascular tone [51]. In addition to the barrier function, the endothelium is responsible for regulating the vasomotor tone, maintaining a normal blood pressure, and consequently upholding laminar flow. Disturbed flow leads to increased permeability and is strongly correlated with atherosclerosis $[52,53]$.

\subsection{Vasomotor Function}

Vasomotor tone is maintained by the release of numerous dilators and constrictors of which nitric oxide (NO) is the most important [54]. ECs metabolize L-arginine via the endothelial isoform of NO synthase (eNOS) to form NO, a process that is subject to both transcriptional and post-translational regulation [55]. Continuous exposure of the endothelium to risk factors such as hyperlipidemia, hypertension, smoking, shear stress, or inflammation leads to eNOS impairment [56]. Decreased NO availability results in inflammatory EC activation by upregulation of adhesion molecules such as ICAM-1 and VCAM-1, NF-KB mediated cytokine expression and disruption of the anti-thrombotic surface of the ECs. Other endothelium-derived vasodilators include prostacyclin and bradykinin. Bradykinin stimulates release of NO, prostacyclin, and the production of tissue plasminogen activator linking endothelial dysfunction to fibrinolysis. The endothelium also produces vasoconstrictor substances such as the very potent endothelin and angiotensin II which are counteracted by NO. Angiotensin II is also an antioxidant and enhances endothelin production and both stimulate VSMC proliferation, thereby contributing to atherosclerotic lesion formation [57].

\section{Endothelial Activation and Leukocyte Transendothelial Migration}

Ox-LDL, damage associated molecular patterns (DAMPS), and pathogen associated molecular patterns (PAMPs), as well as disturbed flow can activate the endothelium $[58,59]$ in part by upregulation of Toll-like receptors (TLRs). TLR downstream signaling results in induction of the NF-kB-pathway, and downstream cytokine (a.o. TNF- $\alpha$ and MCP-1) and interferon production $[60,61]$. This, in turn, mediates the upregulation of adhesion molecules such as VCAM-1 and ICAM-1 [62-64]. Targeting this pathway could therefore decrease the inflammatory response and reduce leukocyte transmigration. NF-kB-pathway blockade resulted in decreased leukocyte TEM and TNF- $\alpha$-induced expression of adhesion molecules $[65,66]$.

Inflammatory cytokines and chemokines, such as TNF- $\alpha$ that are secreted by activated ECs can recruit leukocytes to sites of inflammation and initiate the process of leukocyte transmigration [67]. Furthermore, inflammatory activation of ECs triggers redistribution and upregulation of adhesion molecules such as JAM-A in vitro as well in vivo $[68,69]$. Upregulation and redistribution of adhesion molecules from EC junctions to the apical side of the EC mediates the inflammatory response [70].

Internalization of junctional adhesion molecules also regulates leukocyte TEM. In response to inflammatory stimuli, VE-cadherin-based junctions are disrupted, disassembled, and internalized from the membrane into the cytosol and ultimately degraded leading to increased vascular permeability and increased leukocyte transmigration [71]. In vitro it 
has been shown that ox-LDL promotes monocyte transmigration partially through downregulating VE-cadherin function and weakening of endothelial junctions [72].

Adhesion of leukocytes to and migration across the vessel wall into the underlying tissue occurs constitutively, but the frequency can increase in response to various stimuli and different conditions, such as endothelial activation, dysfunction, and inflammation [73]. Despite the variety in the specific mechanisms utilized by different leukocytes to cross different vascular beds, there is a general principle of capture, rolling, slow rolling, arrest, crawling, and ultimately diapedesis via a paracellular or transcellular route [1,74].

\subsection{Finding Sites of Extravasation}

Adhesion molecules expressed on ECs (e.g., selectins, CAMs), or chemokines and chemoattractants as well as shear stress can guide leukocytes to sites of extravasation. Presence of shear stress is mandatory for lymphocyte TEM in vitro [75]. Disturbance of flow results in disruption of VE-cadherin and $\beta$-catenin-mediated cell-cell junctions at cell borders [76]. Cytokines such as TNF- $\alpha$ released by circulating leukocytes stimulate neutrophil transmigration [77]. Prolonged exposure to inflammatory cytokines, upregulates expression of selectins, ICAM-1 and VCAM-1 on the EC surface [74]. For firm leukocyte attachment, activation of integrins is required. Lymphocyte function-associated antigen 1 (LFA-1, expressed by all leukocytes) and macrophage antigen 1 (Mac1, expressed by myeloid cells) are the most important integrins. Inflammatory cytokines, together with Pand E-selectin, can induce conformational changes of these integrins enabling leukocytes to interact with adhesion molecules promoting slow rolling and firm adhesion [78,79]. Lymphocytes, especially $\mathrm{T}$ cells, share some of the recruitment mechanisms with other leukocytes, but also have distinct mechanisms for extravasation. In response to specific major histocompatibility complex (MHC) molecules and cytokines, e.g., IL-12, T cells express different chemokine receptors and selectin ligands to acquire active and migratory phenotypes [74]. Interestingly, ECs can function as antigen presenting cells that also express costimulatory and co-inhibitory molecules as well as cytokines that can lead to activation of T cells [80].

Following firm adhesion, leukocytes crawl on the vascular endothelium, which has been suggested to enable adhering cells to find optimal sites for extravasation. Neutrophil crawling is strictly Mac1-dependent [81], whereas monocyte crawling can be Mac1- as well as LFA-1-dependent [82,83].

\subsection{Opening Endothelial Cell Junctions}

Once leukocytes are guided to sites of extravasation, "docking structures" are formed that strongly correlate with leukocyte diapedesis and are therefore termed transmigratory cups $[84,85]$. These structures are enriched for ICAM- 1 and VCAM- 1 and consist of actinrich membranes that can form microvilli-like protrusions, which "grasp" the leukocytes [86]. (Figure 2) The formation of these endothelial structures depends on intracellular ICAM-1 engagement and subsequent downstream activation of small GTPase RhoG through the RhoGEF SGEF [87]. Trio induces formation of docking structures through activation of RhoG and Rac1. Reducing Trio activity resulted in decreased leukocyte transmigration [88].

There are two ways for leukocyte TEM: either through the EC body, i.e., transcellular, or through intercellular junctions, i.e., paracellular. Although it has been observed in vitro and in vivo that most leukocytes migrate paracellularly, the transcellular route is also used $[84,89]$. Various cell surface receptors are involved in diapedesis including JAMs, VE-cadherin, and PECAM-1. Leukocytes expressing LFA-1 can bind to endothelial JAM-A and blockade of JAM-A reduced T cell TEM under both physiological and inflammatory conditions [90]. Moreover, JAM-A has been shown to be upregulated in human and mouse atherosclerotic plaques [91]. JAM-C interacts with leukocyte Mac-1 and prevents reverse transmigration of neutrophils [92] and, together with JAM-A, mediates polarization signals that facilitate neutrophil TEM $[89,93]$. 

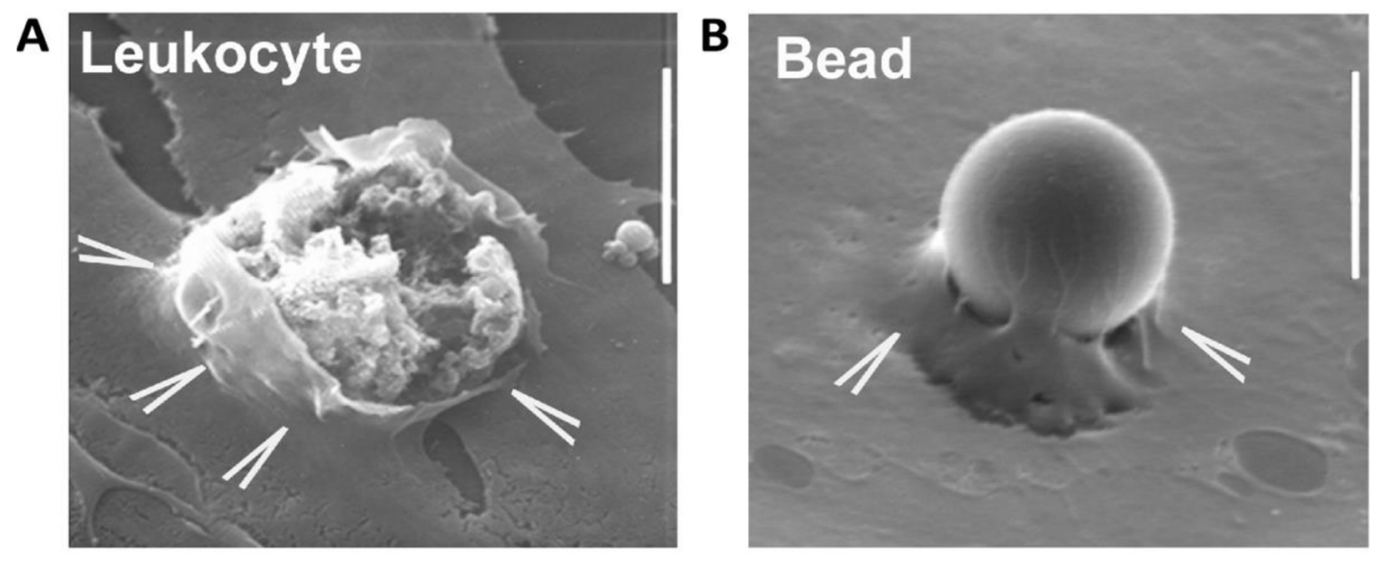

Figure 2. Leukocyte and static bead transmigration. Protrusive membranes (Endothelial protrusions, indicated by the arrowheads) arise from the apical endothelial surface and surround a leukocyte (A) or a static bead (B). The protrusions are believed to assist the leukocyte on its way through and limit vascular leakage. The image on the left may represent a transcellular event with the leukocyte on its way through the endothelial cell border, although the openings at the endothelial level may also suggest that this is a paracellular event. Scale bar: $10 \mu \mathrm{m}$.

As established, PECAM-1, is expressed on ECs, platelets, and leukocytes, but has distinct functions on each cell type. Antibodies blocking endothelial PECAM-1 increase vascular permeability [94] and it was therefore assumed that increasing PECAM-1 expression could reduce vascular permeability and thus leukocyte TEM by increasing cell-cell junction stability. However, PECAM-1 also inhibits activation of platelets and leukocytes [95]. PECAM-1-deficient mice have an excessive inflammatory response and therefore exhibit increased disease severity, $[96,97]$ which is not only due to T cell hyperresponsiveness but also attributed to increased vascular permeability [98]. Increasing PECAM-1 expression on ECs, therefore, is an attractive target to inhibit leukocyte TEM, but the effects of PECAM-1 agonizing antibodies are most likely also derived from the immunomodulatory role of PECAM-1 on leukocytes rather than solely the effect on PECAM-1 expressed by ECs.

CD99 is a heavily glycosylated transmembrane protein that is expressed on leukocytes and ECs and is involved in leukocyte transmigration. Blocking of CD99 results in decreased migration of monocytes and neutrophils $[99,100]$. Specifically, blocking of CD99 resulted in arrest of both neutrophils and monocytes within EC junctions, whereas blockade of PECAM-1 resulted in arrest on the apical surface of the endothelium [99,100]. Different adhesion molecules act sequentially during diapedesis since deletion or blockade of ICAM-2, JAM-A, PECAM-1, and CD99 leads to arrest of leukocytes at different steps of TEM $[99,101]$.

As previously established, VE-cadherin plays a central role in diapedesis. Preventing the dissociation of VE-PTP from VE-cadherin inhibits induction of vascular permeability and consequently leukocyte TEM [102]. Leukocyte-EC interaction can trigger this dissociation, thus promoting diapedesis. Interestingly, VEGF, can also trigger VE-PTP and VE-cadherin dissociation [103].

\subsection{Leukocyte Migration into the Vessel Wall}

After migration through the endothelial monolayer, which occurs within 2-5 min, leukocytes need to pass the endothelial basement membrane, which takes 20-30 min [104,105]. Although this indicates that passage across the basement membrane is a key rate-limiting step, this process is poorly understood [106]. It has been suggested that migration takes place at sites of the basement membrane that express low laminin and collagen IV [106-108]. Laminin 511 inhibits leukocyte transmigration by increasing junctional VE-cadherin and Laminin $\alpha 5$ was found to selectively inhibit T cell TEM through inhibition of T cell integrins $[106,109]$. Upon exposure to inflammatory cytokines and angiogenic factors, ECs produce matrix-degrading enzymes, such as matrix metalloproteinases (MMPs), resulting 
in decreased ECM protein content, which favors leukocyte TEM. For example, activity of a disintegrin and metalloproteinase (ADAM) 10 is required for leukocyte TEM [110]. Evidence also suggests that transmigrating leukocytes induce remodeling of the basement membrane via their proteases such as neutrophil elastase, but the exact mechanisms are not yet discovered [108,111].

\subsection{Vascular Bed Specific TEM}

Like leukocyte TEM under physiologic condition, TEM under inflammatory conditions is condition-specific, which is derived from EC heterogeneity. Single cell analysis of murine ECs from 11 tissues has identified 78 EC subclusters [112]. This analysis revealed that the tissue rather than the vascular bed determines EC heterogeneity, with capillary ECs exhibiting more tissue-specific variation than arterial and venous ECs. This is to be expected as exchange of nutrients primarily takes place at a capillary level. The recent discovery of EC heterogeneity is in line with prior findings that indicate tissue specific mechanisms for leukocyte TEM [113].

\section{Atherosclerosis and Barrier Function}

Endothelial dysfunction has proven to be an early marker for atherosclerosis [114]. In early stages of atherosclerosis, LDL molecules accumulate in the subendothelial region, where these molecules are then oxidized [115]. This is a major trigger for endothelial dysfunction, together with activation of TLRs by DAMPs. Targeting ox-LDL or modulation of TLRs clearly influences the influx of inflammatory cells in the vessel wall $[60,116,117]$. Ox-LDL, can cause upregulation and redistribution of, e.g., JAM-A which promotes lesion formation and leukocyte infiltration [68]. Genetic deletion of JAM-A on ECs reduced plaque size and monocyte and T cell presence in vivo, whereas genetic deletion of JAM-A on leukocytes did not decrease plaque size but did reduce monocyte and $\mathrm{T}$ cell presence. Moreover, transmigration of JAM-A ${ }^{-/-}$monocytes over these JAM-A ${ }^{-/-}$EC was decreased ex vivo compared to JAM-A ${ }^{+/+}$monocytes. This highlights the cell-specific contributions of adhesion molecules.

In vivo EC activation and leukocyte transmigration can be inhibited by genetically or targeted inhibition of adhesion molecules. Inhibition of VCAM-1, either by genetic alteration or antagonizing antibodies, reduced plaque formation and infiltration of leukocytes $[118,119]$. Similarly, deficiency of ICAM-1 impaired lesion formation and soluble ICAM-1 correlated with disease severity [120]. Genetic deletion of SGEF resulted in decreased atherosclerosis by reducing docking structure formation (enriched with ICAM-1) and monocyte infiltration [121]. Genetic deletion of P- and E- selectin reduced plaque size and calcification in both early and advanced lesions [122]. Moreover, in the downstream processes, for instance, by EC specific inhibition of NF- $\mathrm{BB}$ reduced plaque formation, comparable effects such as decreased expression of VCAM-1 on ECs and cytokines in the aorta and impaired macrophage infiltration were observed [123].

It was found that the organization of VE-cadherin-based junctions at plaque endothelium was disorganized and frequently discontinued compared to normal endothelium [124]. Intriguingly, advanced plaque endothelium was found to be more organized than early atherosclerotic plaque endothelium and have improved luminal endothelial barrier function.

Polymorphisms of PECAM-1 are associated with endothelial dysfunction and adverse cardiovascular events in humans $[125,126]$. Interestingly, PECAM-1 has atherogenic or atheroprotective effects depending on the local hemodynamic environment. PECAM-1 deficiency protects from plaque formation in the inner curvature of the aortic arch (low flow) but enhances plaque formation in the descending aorta (high laminar flow) [127-129]. Inhibition of PECAM-1 decreased NF- $\mathrm{BB}$-activation in response to atheroprone flow [128] and PECAM-1 deficiency reduced macrophage content, under low shear conditions [127].

Part of the extracellular domain of PECAM-1 expressed on T cells can be enzymatically shed upon T-cell receptor stimulation, whilst a juxta-membrane extracellular sequence remains expressed. This then can still be phosphorylated and in contrast inhibits $\mathrm{T}$ cell 
activation upon stimulation [130]. Loss of PECAM-1-expression on T-cells is associated with $\mathrm{T}$ cell hyperresponsiveness and atherothrombotic complications in humans and mice [131]. PECAM-1-agonizing antibodies decrease lesion formation, intraplaque hemorrhage, and intraplaque angiogenesis by reducing $\mathrm{T}$ cell activation and infiltration and increasing circulating regulatory $T\left(T_{\text {reg }}\right)$ cells $[129,132]$. These $T_{\text {reg }}$ cells have anti-inflammatory and atheroprotective effects [133] and inhibition or depletion of $\mathrm{T}_{\text {reg }}$ cells is associated with atherosclerosis $[134,135]$. In contrast, other $T$ cell subsets are known to enhance inflammation and exhibit atherogenic effects. T helper $1\left(\mathrm{~T}_{\mathrm{h}} 1\right)$ cells, for example, promote atherosclerosis by secreting pro-inflammatory cytokines such as IFN $\gamma$ [136]. The use of immune checkpoint inhibitors, such as PD1-inhibitors, in cancer to activate T cells, has been shown to result in cardiovascular toxicity in humans [137]. In mice, PD1 deficiency resulted in increased atherosclerosis through exacerbated infiltration of T cells in the lesion [138].

In addition to the previously described adhesion molecules, platelets also play an important role in leukocyte TEM and early atherosclerosis formation. Platelets express various adhesion molecules, such as JAM-A and PECAM-1, and can interact with leukocytes [139]. Atherosclerotic plaque size was increased in platelet specific JAM-A ${ }^{-/}$mice with increased macrophage and $\mathrm{T}$ cell content. Moreover, these platelets exhibited increased binding capacity to leukocytes as well as increased inflammatory activity [140]. In addition to this distinct role in leukocyte recruitment, platelets are also needed to prevent bleeding during diapedesis. In mice with thrombocytopenia, neutrophil diapedesis was responsible for hemorrhaging demonstrating that not only leukocytes and ECs are involved in diapedesis but also other cells such as platelets [141].

\subsection{Plaque Hypoxia}

Once monocytes passage the endothelial barrier and reach the intimal space, colonystimulating factor induces monocytes to phenotypically transform into macrophages and start taking up modified LDL particles [142]. Macrophages release reactive oxygen species (ROS) and inflammatory cytokines (a.o. TNF- $\alpha$, MCP-1, IL-1, IL-6) which contribute to the continued recruitment and activation of other leukocytes. The activated macrophages also secrete MMPs which are clearly associated with plaque destabilization [143]. Macrophage activation involves a lot of metabolic processes resulting in a macrophage phenotype that is hypoxia inducible factor $1 \alpha(\mathrm{HIF}-1 \alpha)$ dependent $[144,145]$. Upon transformation into foam cells, macrophages may undergo necrosis and thereby contribute to the necrotic core of advanced lesions. These advanced lesions are characterized by an increased vessel wall thickness resulting in regional limited oxygen exchange and thus hypoxic regions [146,147]. In a model of vein graft atherosclerosis, hypoxia replacement therapy resulted in enhanced vein graft patency and plaque stability via ROS mediated apoptosis of macrophages [148]. The oxygen-sensitive transcription factor HIF- $1 \alpha$ is crucial in the adaptation to the local hypoxia status. HIF- $1 \alpha$ induces transcription of hypoxia responsive genes such as VEGF, fibroblast growth factor, cytokines, and angiopoietins (Angs). Silencing of HIF-1 $\alpha$ in macrophages reduces proinflammatory factors and increases macrophage apoptosis [149]. In contrast, deficiency of HIF- $1 \alpha$ in antigen presenting cells induces $T_{h} 1$ polarization and aggravation of atherosclerosis via increased production of inflammatory cytokines [150].

\subsection{Intraplaque Angiogenesis and Intraplaque Hemorrhage}

Due to the hypoxia, plaque neovessels are formed through the HIF-1 $\alpha$-mediated transcription of angiogenic factors such as VEGF, to match the increased demand of oxygen in the plaque. VEGF, and activation of VEGFR2, promotes internalization of VE-cadherin and mediates the behavioral switch of ECs from a quiescent to an invasive phenotype leading to proliferation and migration of ECs into the plaque [151,152]. In turn, VE-cadherin limits VEGFR2 activation [153]. VEGF also induces ADAM10 and ADAM17 activity in ECs, mediating VE-cadherin cleavage [154]. It is thought that the ECs triggered by activation of VEGFR2 grow from the existing adventitial vasa vasorum into the atherosclerotic plaque [155]. In addition, Ang2 is upregulated and enhances angiogenesis by inducing 
detachment of pericytes to enable EC migration [156]. Moreover, Ang2 antagonizes Ang1, which promotes vessel maturation by recruiting pericytes, decreasing PECAM- 1 and VEcadherin phosphorylation. Ang2 also decreases basal and VEGF-induced permeability, thus protecting against plasma leakage and inhibiting leukocyte TEM [155,157]. Ang2, therefore, strongly compromises vessel maturation, yielding plaque neovessels with diminished structural integrity due to incomplete or absent endothelial junctions, basement membrane detachment and poor pericyte coverage rendering high susceptibility to vascular leakage [7]. Moreover, these ECs exhibit an activated and dysfunctional phenotype [7]. Indeed, intraplaque angiogenesis leads to intraplaque hemorrhage and plaque neovessels are co-localized with erythrocytes and immune cells. (Figures 3 and 4A) [158]. In addition, erythrocytes are known to interact with the endothelium to facilitate and enhance influx of leukocytes into the plaque [159].

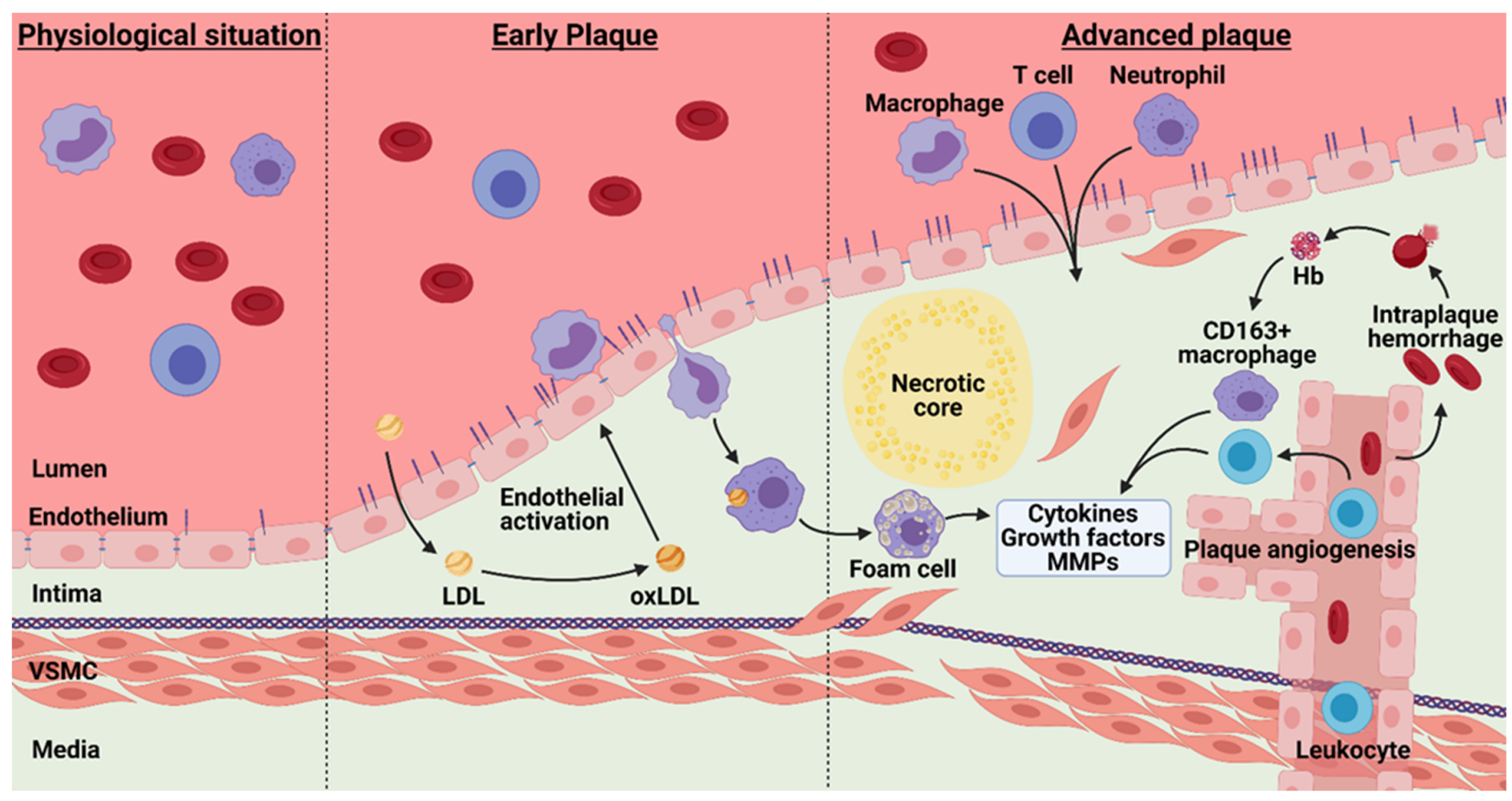

Figure 3. Pathophysiology of early and advanced atherosclerosis. Upon transcytosis and oxidation of LDL, the endothelium becomes activated leading to leukocyte infiltration into the vessel wall. This triggers thickening of the intimal layer, ultimately resulting in foam cell accumulation and necrotic core formation. Hypoxia induces intra-plaque angiogenesis, but these neovessels are often mature which leads to intraplaque hemorrhage and excessive extravasation of leukocytes. This results in production of cytokines, growth factors and MMPs, creating a continuous loop of plaque growth and ultimately plaque rupture. $\mathrm{Hb}$ - hemoglobin; LDL—low-density lipoproteins; MMPs—metallo matrix proteinases; oxLDL—oxidized low-density lipoproteins; VSMC—vascular smooth muscle cell.

\subsection{Angiogenesis Associated Macrophages}

Once extravasated, erythrocytes lyse quickly, exposing hemoglobin which attracts monocytes and neutrophils into the plaque $[160,161]$. Macrophages can take up hemoglobin by CD163 leading to a distinct, alternative, non-foam cell macrophage phenotype [162]. These $\mathrm{CD} 163^{+}$macrophages are abundantly present in human and murine plaques expressing HIF- $1 \alpha$ and VEGF, upregulating VCAM and associating with intraplaque angiogenesis and vascular permeability [163,164] (Figure 4B). Genetic analyses indicated that polymorphisms that result in increased CD163 expression and are a risk factor for plaque rupture [163]. Genetic deletion of CD163 in mice reduced plaque neovascularization, intraplaque hemorrhage and plaque progression. Regions in the plaque that exhibit active inflammation, determined by, e.g., macrophage content and MHC2-expression, show 
increased microvessel density in humans [165]. In advanced human lesions, ADAM17 expressing cells colocalize with CD68+-cells and ADAM17 is also associated with plaqueprogression and neovascularization [153,166,167].
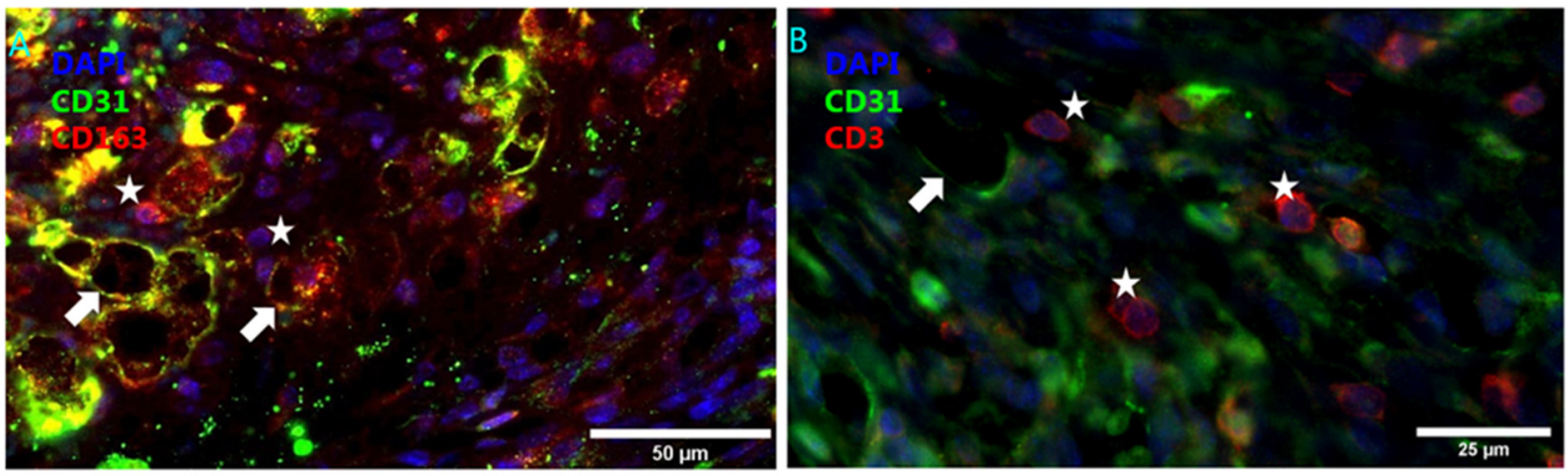

Figure 4. Inflammatory cell association with plaque neovessels. Inflammatory cells (indicated by stars) located near neovessels (indicated by arrows) in murine atherosclerotic vein grafts (A) Hemoglobin associated CD163+ macrophages localizing near neovessels, DAPI (blue), CD31 (green), and CD163 (red) (B) CD3+ T cells localizing near neovessels, DAPI (blue), CD31 (green) and CD3 (red).

Extravasated inflammatory cells secrete growth factors, cytokines and MMPs, fueling intraplaque angiogenesis creating a continuous loop of plaque growth [168]. Intraplaque angiogenesis and consequently intraplaque hemorrhage are associated with plaque growth, instability, and ultimately rupture [169]. Targeting neovascularization may therefore stand as a promising approach to reduce atherosclerotic disease burden. Blockade of VEGFR2 in a murine vein graft atherosclerosis model decreased intraplaque hemorrhage, resulting in more stable atherosclerotic lesions with increased EC junctions with reduced macrophage content in vivo and increased pericyte coverage in vitro [164]. Adding to that, inhibition of basic fibroblast growth factor in the same vein graft atherosclerosis model resulted in decreased intraplaque angiogenesis and hemorrhage as well as reducing macrophage infiltration by reducing VCAM-1 expression [170]. Interestingly, myeloid ADAM17 deficiency is pro-atherosclerotic due to reduced shedding of TNF-receptor2 leading to sustained proinflammatory signaling. In contrast, endothelial ADAM17 deficiency is atheroprotective by mechanisms yet to be elucidated [171].

\subsection{Statins}

Statins are currently the principal drug in prevention of coronary artery disease (CAD) [172]. They hamper atherosclerosis progression by lowering LDL plasma levels, [173] but they have also been found to improve EC function and reduce inflammation [174-176]. Statins inhibit LFA-1 leading to decreased interactions with ICAM-1 and T cell activation [176] and reduce neutrophil transmigration by reducing Rho activity [117]. Intraplaque angiogenesis was found to be reduced in patients treated with atorvastatin compared to non-treated patients [177]. In mice, atorvastatin reduced neovessel formation whilst improving vessel maturation leading to decreased intraplaque hemorrhage in vivo. Atorvastatin was shown to increase VE-cadherin expression and pericyte coverage ex vivo and inhibit Ang2 release as well as VE-cadherin phosphorylation in vitro [28].

\subsection{Atherosclerosis Heterogeneity}

In line with EC heterogeneity, the degree of atherosclerosis differs in the various segments of the vascular tree. In CAD, for example, several studies have shown that proximal lesions are more frequently observed than distal lesions, possibly due to disturbed flow [178-180]. In addition, atherosclerosis also differs across different vascular beds. There is great distinction between intracranial (IC) and atherosclerosis in other vascular beds. Both can lead to severe ischemic events such as stroke, MI, and PAD. 
IC atherosclerosis develops at a later age [181], but progression occurs more rapidly compared to the linear progression that is seen in atherosclerosis at other vascular beds [182] Intracranial arteries have decreased permeability due to higher number TJs, which results in decreased susceptibility to inflammation [183]. In rabbits, ox-LDL impaired vasocontraction and -dilatation in the carotid but not in the basilar artery, suggesting that IC arteries might be more resistant to ox-LDL [184]. In addition, IC arteries have a distinct morphology, which may also contribute to the initial resistance of IC arteries to atherosclerosis together with EC heterogeneity [112] may also contribute to the initial resistance of IC arteries to atherosclerosis. Vasa vasorum are initially absent IC arteries and develop only as a result of pathophysiological vessel wall thickening [185,186].

The variety between the arterial beds adds to the different forms of atherosclerosis (e.g., between coronary and peripheral atherosclerosis) [187]. In general, peripheral lesions have more calcifications but have a more stable phenotype compared to coronary lesions. In addition, peripheral lesions develop more slowly, but are more diffuse $[188,189]$. The increased susceptibility to atherosclerosis of the coronary arteries compared to peripheral arteries has been attributed to increased vasa vasorum density in coronary arteries [190].

\section{Future Directions}

Restoring endothelial barrier function and consequently reducing leukocyte transmigration could be an effective strategy to decrease atherogenesis. Moreover, reducing endothelial dysfunction would also improve quality of the neovessels present and consequently reduce intraplaque hemorrhage. Using local therapy targeting vascular bed specific abnormalities could prevent plaque progression with limited side-effects. Knowledge on endothelial dysfunction, plaque angiogenesis and vascular bed specific atherosclerosis is limited, and more research is needed to utilize its therapeutic potential to its fullest.

Author Contributions: All authors designed the concept, T.J.S. and M.R.d.V. wrote the manuscript and J.D.v.B., S.H. and P.H.A.Q. provided substantial feedback. All authors have read and agreed to the published version of the manuscript.

Funding: This work was supported by a grant from the Rembrandt Institute for Cardiovascular Science (RICS) to J.D.v.B, S.H., and M.R.d.V.

Institutional Review Board Statement: Not applicable.

Informed Consent Statement: Not applicable.

Data Availability Statement: Not applicable.

Conflicts of Interest: The authors declare no conflict of interest.

Ethical Approval: This article does not contain any studies with human participants performed by any of the authors. All applicable international, national, and/or institutional guidelines for the care and use of animals were followed.

\section{References}

1. Vestweber, D. How leukocytes cross the vascular endothelium. Nat. Rev. Immunol. 2015, 156, 92-704. [CrossRef]

2. Owen-Woods, C.; Joulia, R.; Barkaway, A.; Rolas, L.; Ma, B.; Nottebaum, A.F.; Arkill, K.P.; Stein, M.; Girbl, T.; Golding, M.; et al. Local microvascular leakage promotes trafficking of activated neutrophils to remote organs. J. Clin. Investig. 2020, 1302, 301-318. [CrossRef]

3. De Vries, M.R.; Quax, P.H.A. Inflammation in Vein Graft Disease. Front. Cardiovasc. Med. 2018, 5, 3. [CrossRef]

4. Heemskerk, N.; Schimmel, L.; Oort, C.; van Rijssel, J.; Yin, T.; Ma, B.; van Unen, J.; Pitter, B.; Huveneers, S.; Goedhart, J.; et al. F-actin-rich contractile endothelial pores prevent vascular leakage during leukocyte diapedesis through local RhoA signalling. Nat. Commun. 2016, 71, 0493. [CrossRef]

5. Eriksson, E.E. Intravital microscopy on atherosclerosis in apolipoprotein e-deficient mice establishes microvessels as major entry pathways for leukocytes to advanced lesions. Circulation 2011, 1242, 129-138. [CrossRef]

6. De Vries, M.R.; Niessen, H.W.; Löwik, C.W.; Hamming, J.F.; Jukema, J.W.; Quax, P.H. Plaque rupture complications in murine atherosclerotic vein grafts can be prevented by TIMP-1 overexpression. PLoS ONE 2012, 7, e47134. [CrossRef] 
7. Sluimer, J.C.; Kolodgie, F.D.; Bijnens, A.P.; Maxfield, K.; Pacheco, E.; Kutys, B.; Duimel, H.; Frederik, P.M.; van Hinsbergh, V.M.; Virmani, R.; et al. Thin-walled microvessels in human coronary atherosclerotic plaques show incomplete endothelial junctions relevance of compromised structural integrity for intraplaque microvascular leakage. J. Am. Coll. Cardiol. 2009, 531, 517-527.

8. Radeva, M.Y.; Waschke, J. Mind the gap: Mechanisms regulating the endothelial barrier. Acta Physiol. Oxf. 2018, 222 , e12860. [CrossRef]

9. Komarova, Y.A.; Kruse, K.; Mehta, D.; Malik, A.B. Protein Interactions at Endothelial Junctions and Signaling Mechanisms Regulating Endothelial Permeability. Circ. Res. 2017, 1201, 79-206. [CrossRef]

10. Qu, Y.; Dahl, G. Accessibility of cx46 hemichannels for uncharged molecules and its modulation by voltage. Biophys. J. 2004, 861, 502-509. [CrossRef]

11. Augustin, H.G.; Koh, G.Y. Organotypic vasculature: From descriptive heterogeneity to functional pathophysiology. Science 2017, 357. [CrossRef]

12. Aird, W.C. Phenotypic heterogeneity of the endothelium: II. Representative vascular beds. Circ. Res. 2007, 1001, 74-90. [CrossRef]

13. Shakib, M.; Cunha-Vaz, J.G. Studies on the permeability of the blood-retinal barrier. IV. Junctional complexes of the retinal vessels and their role in the permeability of the blood-retinal barrier. Exp. Eye Res. 1966, 52, 29-34.

14. Abdullahi, W.; Tripathi, D.; Ronaldson, P.T. Blood-brain barrier dysfunction in ischemic stroke: Targeting tight junctions and transporters for vascular protection. Am. J. Physiol. Cell Physiol. 2018, 315, C343-C356. [CrossRef]

15. Nitta, T.; Hata, M.; Gotoh, S.; Seo, Y.; Sasaki, H.; Hashimoto, N.; Furuse, M.; Tsukita, S. Size-selective loosening of the blood-brain barrier in claudin-5-deficient mice. J. Cell Biol. 2003, 1616, 53-60. [CrossRef]

16. Ebnet, K. Junctional Adhesion Molecules (JAMs): Cell Adhesion Receptors With Pleiotropic Functions in Cell Physiology and Development. Physiol. Rev. 2017, 971, 529-554. [CrossRef] [PubMed]

17. Itoh, M.; Furuse, M.; Morita, K.; Kubota, K.; Saitou, M.; Tsukita, S. Direct binding of three tight junction-associated MAGUKs.; ZO-1.; ZO-2.; and ZO-3.; with the COOH termini of claudins. J. Cell Biol. 1999, 1471, 351-363. [CrossRef]

18. Tornavaca, O.; Chia, M.; Dufton, N.; Almagro, L.O.; Conway, D.E.; Randi, A.M.; Schwartz, M.A.; Matter, K.; Balda, M.S. ZO-1 controls endothelial adherens junctions.; cell-cell tension.; angiogenesis.; and barrier formation. J. Cell Biol. 2015, $2088,21-38$. [CrossRef]

19. Shigetomi, K.; Ono, Y.; Inai, T.; Ikenouchi, J. Adherens junctions influence tight junction formation via changes in membrane lipid composition. J. Cell Biol. 2018, 2172, 373-381. [CrossRef]

20. Taddei, A.; Giampietro, C.; Conti, A.; Orsenigo, F.; Breviario, F.; Pirazzoli, V.; Potente, M.; Daly, C.; Dimmeler, S.; Dejana, E. Endothelial adherens junctions control tight junctions by VE-cadherin-mediated upregulation of claudin-5. Nat. Cell Biol. 2008, 109, 23-34. [CrossRef]

21. Dejana, E.; Orsenigo, F.; Molendini, C.; Baluk, P.; McDonald, D.M. Organization and signaling of endothelial cell-to-cell junctions in various regions of the blood and lymphatic vascular trees. Cell Tissue Res. 2009, 3351, 7-25. [CrossRef]

22. Lertkiatmongkol, P.; Liao, D.; Mei, H.; Hu, Y.; Newman, P.J. Endothelial functions of platelet/endothelial cell adhesion molecule-1 (CD31). Curr. Opin. Hematol. 2016, 232, 53-59. [CrossRef]

23. Yap, A.S.; Niessen, C.M.; Gumbiner, B.M. The juxtamembrane region of the cadherin cytoplasmic tail supports lateral clustering.; adhesive strengthening.; and interaction with p120ctn. J. Cell Biol. 1998, 1417, 79-89. [CrossRef]

24. Angulo-Urarte, A.; van der Wal, T.; Huveneers, S. Cell-cell junctions as sensors and transducers of mechanical forces. Biochim. Biophys. Acta Biomembr. 2020, 18621, 83316.

25. Schulte, D.; Küppers, V.; Dartsch, N.; Broermann, A.; Li, H.; Zarbock, A.; Kamenyeva, O.; Kiefer, F.; Khandoga, A.; Massberg, S.; et al. Stabilizing the VE-cadherin-catenin complex blocks leukocyte extravasation and vascular permeability. EMBO J. 2011, 304, 157-170. [CrossRef]

26. Orlova, V.V.; Economopoulou, M.; Lupu, F.; Santoso, S.; Chavakis, T. Junctional adhesion molecule-C regulates vascular endothelial permeability by modulating VE-cadherin-mediated cell-cell contacts. J. Exp. Med. 2006, 2032, 703-714.

27. Potter, M.D.; Barbero, S.; Cheresh, D.A. Tyrosine phosphorylation of VE-cadherin prevents binding of p120- and beta-catenin and maintains the cellular mesenchymal state. J. Biol. Chem. 2005, 2803, 1906-1912.

28. Baganha, F.; Jong, R.C.M.D.; Peters, E.A.; Voorham, W.; Jukema, J.W.; Delibegovic, M.; de Vries, M.R.; Quax, P.H.A. Atorvastatin pleiotropically decreases intraplaque angiogenesis and intraplaque haemorrhage by inhibiting ANGPT2 release and VE-Cadherin internalization. Angiogenesis 2021. [CrossRef]

29. Lampugnani, M.G.; Corada, M.; Andriopoulou, P.; Esser, S.; Risau, W.; Dejana, E. Cell confluence regulates tyrosine phosphorylation of adherens junction components in endothelial cells. J. Cell Sci. 1997, 110 Pt 17, 2065-2077.

30. Wessel, F.; Winderlich, M.; Holm, M.; Frye, M.; Rivera-Galdos, R.; Vockel, M.; Linnepe, R.; Ipe, U.; Stadtmann, A.; Zarbock, A.; et al. Leukocyte extravasation and vascular permeability are each controlled in vivo by different tyrosine residues of VE-cadherin. Nat. Immunol. 2014, 152, 23-30. [CrossRef]

31. Nawroth, R.; Poell, G.; Ranft, A.; Kloep, S.; Samulowitz, U.; Fachinger, G.; Golding, M.; Shima, D.T.; Deutsch, U.; Vestweber, D. VE-PTP and VE-cadherin ectodomains interact to facilitate regulation of phosphorylation and cell contacts. EMBO J. 2002, 214, 885-895. [CrossRef]

32. Juettner, V.V.; Kruse, K.; Dan, A.; Vu, V.H.; Khan, Y.; Le, J.; Le, J.; Leckband, D.; Komarova, Y.; Malik, A.B. VE-PTP stabilizes VE-cadherin junctions and the endothelial barrier via a phosphatase-independent mechanism. J. Cell Biol. 2019, 2181, 725-742. [CrossRef] 
33. Van Buul, J.D.; Geerts, D.; Huveneers, S. Rho GAPs and GEFs: Controling switches in endothelial cell adhesion. Cell Adh. Migr. 2014, 81, 08-24. [CrossRef]

34. Timmerman, I.; Heemskerk, N.; Kroon, J.; Schaefer, A.; van Rijssel, J.; Hoogenboezem, M.; van Unen, J.; Goedhart, J.; Gadella, T.W., Jr.; Yin, T.; et al. A local VE-cadherin and Trio-based signaling complex stabilizes endothelial junctions through Rac1. J. Cell Sci. 2015, 1283, 041-054.

35. Privratsky, J.R.; Paddock, C.M.; Florey, O.; Newman, D.K.; Muller, W.A.; Newman, P.J. Relative contribution of PECAM-1 adhesion and signaling to the maintenance of vascular integrity. J. Cell Sci. 2011, 124 Pt 9, 1477-1485. [CrossRef]

36. Machida, K.; Thompson, C.M.; Dierck, K.; Jablonowski, K.; Kärkkäinen, S.; Liu, B.; Zhang, H.; Nash, P.D.; Newman, D.K.; Nollau, P.; et al. High-throughput phosphotyrosine profiling using SH2 domains. Mol. Cell 2007, 268, 99-915. [CrossRef]

37. Caligiuri, G. Mechanotransduction, immunoregulation, and metabolic functions of CD31 in cardiovascular pathophysiology. Cardiovasc. Res. 2019, 1151, 425-434. [CrossRef]

38. Biswas, P.; Canosa, S.; Schoenfeld, D.; Schoenfeld, J.; Li, P.; Cheas, L.C.; Zhang, J.; Cordova, A.; Sumpio, B.; Madri, J.A. PECAM-1 affects GSK-3beta-mediated beta-catenin phosphorylation and degradation. Am. J. Pathol. 2006, 1693, 14-24.

39. Tzima, E.; Irani-Tehrani, M.; Kiosses, W.B.; Dejana, E.; Schultz, D.A.; Engelhardt, B.; Cao, G.; DeLisser, H.; Schwartz, M.A. A mechanosensory complex that mediates the endothelial cell response to fluid shear stress. Nature 2005, 4374, 26-31. [CrossRef]

40. Garnacho, C.; Shuvaev, V.; Thomas, A.; McKenna, L.; Sun, J.; Koval, M.; Albelda, S.; Muzykantov, V.; Muro, S. RhoA activation and actin reorganization involved in endothelial CAM-mediated endocytosis of anti-PECAM carriers: Critical role for tyrosine 686 in the cytoplasmic tail of PECAM-1. Blood 2008, 1113, 024-033. [CrossRef]

41. Claesson-Welsh, L.; Dejana, E.; McDonald, D.M. Permeability of the Endothelial Barrier: Identifying and Reconciling Controversies. Trends Mol. Med. 2020. [CrossRef]

42. Baganha, F.; Ritsma, L.; Quax, P.H.A.; de Vries, M.R. Assessment of Microvessel Permeability in Murine Atherosclerotic Vein Grafts Using Two-Photon Intravital Microscopy. Int. J. Mol. Sci. 2020, 21, 9244. [CrossRef] [PubMed]

43. Mitra, R.; O’Neil, G.L.; Harding, I.C.; Cheng, M.J.; Mensah, S.A.; Ebong, E.E. Glycocalyx in Atherosclerosis-Relevant Endothelium Function and as a Therapeutic Target. Curr. Atheroscler. Rep. 2017, 196, 3. [CrossRef]

44. Morris, A.W.; Sharp, M.M.; Albargothy, N.J.; Fernandes, R.; Hawkes, C.A.; Verma, A.; Weller, R.O.; Carare, R.O. Vascular basement membranes as pathways for the passage of fluid into and out of the brain. Acta Neuropathol. 2016, 1317, 25-36. [CrossRef] [PubMed]

45. Sengillo, J.D.; Winkler, E.A.; Walker, C.T.; Sullivan, J.S.; Johnson, M.; Zlokovic, B.V. Deficiency in Mural Vascular Cells Coincides with Blood-Brain Barrier Disruption in Alzheimer's Disease. Brain Pathol. 2013, 233, 3-10. [CrossRef] [PubMed]

46. Perrot, C.Y.; Herrera, J.L.; Fournier-Goss, A.E.; Komatsu, M. Prostaglandin E2 breaks down pericyte-endothelial cell interaction via EP1 and EP4-dependent downregulation of pericyte N-cadherin, connexin-43, and R-Ras. Sci. Rep. 2020, 101, 1186. [CrossRef]

47. Kruse, K.; Lee, Q.S.; Sun, Y.; Klomp, J.; Yang, X.; Huang, F.; Sun, M.Y.; Zhao, S.; Hong, Z.; Vogel, S.M.; et al. N-cadherin signaling via Trio assembles adherens junctions to restrict endothelial permeability. J. Cell Biol. 2019, 2182, 99-316. [CrossRef]

48. Kivelä, R.; Hemanthakumar, K.A.; Vaparanta, K.; Robciuc, M.; Izumiya, Y.; Kidoya, H.; Takakura, N.; Peng, X.; Sawyer, D.B.; Elenius, K.; et al. Endothelial Cells Regulate Physiological Cardiomyocyte Growth via VEGFR2-Mediated Paracrine Signaling. Circulation 2019, 1392, 570-584. [CrossRef]

49. Davis, G.E.; Senger, D.R. Endothelial Extracellular Matrix. Circ. Res. 2005, 971, 093-107. [CrossRef] [PubMed]

50. Ruiz-Torres, M.P.; Pérez-Rivero, G.; Rodríguez-Puyol, M.; Rodríguez-Puyol, D.; Díez-Marqués, M.L. The leukocyte-endothelial cell interactions are modulated by extracellular matrix proteins. Cell Physiol. Biochem. 2006, 17, 221-232. [CrossRef]

51. MacLeod, D.C.; Strauss, B.H.; de Jong, M.; Escaned, J.; Umans, V.A.; van Suylen, R.J.; Verkerk, A.; de Feyter, P.J.; Serruys, P.W. Proliferation and extracellular matrix synthesis of smooth muscle cells cultured from human coronary atherosclerotic and restenotic lesions. J. Am. Coll. Cardiol. 1994, 235, 9-65. [CrossRef]

52. Peng, Z.; Shu, B.; Zhang, Y.; Wang, M. Endothelial Response to Pathophysiological Stress. Arterioscler. Thromb. Vasc. Biol. 2019, 39, e233-e243. [CrossRef]

53. Zhang, C.; Zhou, T.; Chen, Z.; Yan, M.; Li, B.; Lv, H.; Wang, C.; Xiang, S.; Shi, L.; Zhu, Y.; et al. Coupling of Integrin $\alpha 5$ to Annexin A2 by Flow Drives Endothelial Activation. Circ. Res. 2020, 1271, 074-090. [CrossRef] [PubMed]

54. Cardillo, C.; Kilcoyne, C.M.; Cannon, R.O., 3rd; Panza, J.A. Interactions between nitric oxide and endothelin in the regulation of vascular tone of human resistance vessels in vivo. Hypertension 2000, 351, 237-241. [CrossRef]

55. Fleming, I. Molecular mechanisms underlying the activation of eNOS. Pflugers Arch. 2010, 4597, 93-806. [CrossRef]

56. Gimbrone, M.A.; García-Cardeña, G. Endothelial Cell Dysfunction and the Pathobiology of Atherosclerosis. Circ. Res. 2016, 1186, 20-36. [CrossRef] [PubMed]

57. Moreau, P.; d’Uscio, L.V.; Shaw, S.; Takase, H.; Barton, M.; Lüscher, T.F. Angiotensin II Increases Tissue Endothelin and Induces Vascular Hypertrophy. Circulation 1997, 961, 593-597. [CrossRef]

58. Vidal, F.; Colomé, C.; Martínez-González, J.; Badimon, L. Atherogenic concentrations of native low-density lipoproteins downregulate nitric-oxide-synthase mRNA and protein levels in endothelial cells. Eur. J. Biochem. 1998, 2523, 78-84. [CrossRef]

59. Salvador, B.; Arranz, A.; Francisco, S.; Córdoba, L.; Punzón, C.; Llamas, M.; Fresno, M. Modulation of endothelial function by Toll like receptors. Pharmacol. Res. 2016, 1084, 6-56. [CrossRef] 
60. Karper, J.C.; Vries, M.R.D.; Brand, B.T.V.D.; Hoefer, I.E.; Fischer, J.W.; Jukema, J.W.; Niessen, H.W.M.; Quax, P.H.A. Toll-Like Receptor 4 Is Involved in Human and Mouse Vein Graft Remodeling.; and Local Gene Silencing Reduces Vein Graft Disease in Hypercholesterolemic APOE*3Leiden Mice. Arterioscler. Thromb. Vasc. Biol. 2011, 311, 033-040. [CrossRef] [PubMed]

61. Simons, K.H.; Peters, H.A.B.; Jukema, J.W.; de Vries, M.R.; Quax, P.H.A. A protective role of IRF3 and IRF7 signalling downstream TLRs in the development of vein graft disease via type I interferons. J. Intern. Med. 2017, 2825, 22-36. [CrossRef] [PubMed]

62. Rajan, S.; Ye, J.; Bai, S.; Huang, F.; Guo, Y.L. NF-kappaB, but not p38 MAP kinase.; is required for TNF-alpha-induced expression of cell adhesion molecules in endothelial cells. J. Cell Biochem. 2008, 1054, 77-86.

63. Jersmann, H.P.A.; Hii, C.S.T.; Ferrante, J.V.; Ferrante, A. Bacterial Lipopolysaccharide and Tumor Necrosis Factor Alpha Synergistically Increase Expression of Human Endothelial Adhesion Molecules through Activation of NF- $\kappa$ B and p38 MitogenActivated Protein Kinase Signaling Pathways. Infect. Immun. 2001, 691, 273-279. [CrossRef] [PubMed]

64. Denk, A.; Goebeler, M.; Schmid, S.; Berberich, I.; Ritz, O.; Lindemann, D.; Ludwig, S.; Wirth, T. Activation of NF-kappa B via the Ikappa B kinase complex is both essential and sufficient for proinflammatory gene expression in primary endothelial cells. J. Biol. Chem. 2001, 2762, 8451-8458.

65. Sehnert, B.; Burkhardt, H.; Wessels, J.T.; Schröder, A.; May, M.J.; Vestweber, D.; Zwerina, J.; Warnatz, K.; Nimmerjahn, F.; Schett, G.; et al. NF- $\mathrm{kB}$ inhibitor targeted to activated endothelium demonstrates a critical role of endothelial NF- $\mathrm{kB}$ in immune-mediated diseases. Proc. Natl. Acad. Sci. USA 2013, 1101, 6556-6561.

66. Lockyer, J.M.; Colladay, J.S.; Alperin-Lea, W.L.; Hammond, T.; Buda, A.J. Inhibition of nuclear factor-kappaB-mediated adhesion molecule expression in human endothelial cells. Circ. Res. 1998, 823, 14-20.

67. Ranta, V.; Orpana, A.; Carpén, O.; Turpeinen, U.; Ylikorkala, O.; Viinikka, L. Human vascular endothelial cells produce tumor necrosis factor-alpha in response to proinflammatory cytokine stimulation. Crit. Care Med. 1999, 272, $184-187$.

68. Schmitt, M.M.; Megens, R.T.; Zernecke, A.; Bidzhekov, K.; van den Akker, N.M.; Rademakers, T.; van Zandvoort, M.A.; Hackeng, T.M.; Koenen, R.R.; Weber, C. Endothelial junctional adhesion molecule-a guides monocytes into flow-dependent predilection sites of atherosclerosis. Circulation 2014, 1296, 6-76. [CrossRef] [PubMed]

69. Schmitt, M.M.; Fraemohs, L.; Hackeng, T.M.; Weber, C.; Koenen, R.R. Atherogenic mononuclear cell recruitment is facilitated by oxidized lipoprotein-induced endothelial junctional adhesion molecule-A redistribution. Atherosclerosis 2014, $2342,54-64$. [CrossRef]

70. Reglero-Real, N.; Colom, B.; Bodkin, J.V.; Nourshargh, S. Endothelial Cell Junctional Adhesion Molecules: Role and Regulation of Expression in Inflammation. Arterioscler. Thromb. Vasc. Biol. 2016, 362, 048-057. [CrossRef]

71. Chan, Y.H.; Harith, H.H.; Israf, D.A.; Tham, C.L. Differential Regulation of LPS-Mediated VE-Cadherin Disruption in Human Endothelial Cells and the Underlying Signaling Pathways: A Mini Review. Front. Cell Dev. Biol. 2020, 7, 280. [CrossRef] [PubMed]

72. Hashimoto, K.; Kataoka, N.; Nakamura, E.; Tsujioka, K.; Kajiya, F. Oxidized LDL specifically promotes the initiation of monocyte invasion during transendothelial migration with upregulated PECAM-1 and downregulated VE-cadherin on endothelial junctions. Atherosclerosis 2007, 194, e9-e17. [CrossRef] [PubMed]

73. Hordijk, P.L. Recent insights into endothelial control of leukocyte extravasation. Cell Mol. Life Sci. 2016, 731, 591-608. [CrossRef]

74. Schnoor, M.; Alcaide, P.; Voisin, M.B.; van Buul, J.D. Crossing the Vascular Wall: Common and Unique Mechanisms Exploited by Different Leukocyte Subsets during Extravasation. Mediat. Inflamm. 2015, 20159, 46509. [CrossRef] [PubMed]

75. Cinamon, G.; Shinder, V.; Alon, R. Shear forces promote lymphocyte migration across vascular endothelium bearing apical chemokines. Nat. Immunol. 2001, 25, 15-22. [CrossRef]

76. Miao, H.; Hu, Y.L.; Shiu, Y.T.; Yuan, S.; Zhao, Y.; Kaunas, R.; Wang, Y.; Jin, G.; Usami, S.; Chien, S. Effects of flow patterns on the localization and expression of VE-cadherin at vascular endothelial cell junctions: In vivo and in vitro investigations. J. Vasc. Res. 2005, 427, 7-89. [CrossRef]

77. Finsterbusch, M.; Voisin, M.B.; Beyrau, M.; Williams, T.J.; Nourshargh, S. Neutrophils recruited by chemoattractants in vivo induce microvascular plasma protein leakage through secretion of TNF. J. Exp. Med. 2014, 2111, 307-314. [CrossRef]

78. Zarbock, A.; Ley, K.; McEver, R.P.; Hidalgo, A. Leukocyte ligands for endothelial selectins: Specialized glycoconjugates that mediate rolling and signaling under flow. Blood 2011, 1186, 743-751. [CrossRef]

79. Alon, R.; Shulman, Z. Chemokine triggered integrin activation and actin remodeling events guiding lymphocyte migration across vascular barriers. Exp. Cell Res. 2011, 3176, 32-41. [CrossRef]

80. Carman, C.V.; Martinelli, R.T. Lymphocyte-Endothelial Interactions: Emerging Understanding of Trafficking and Antigen-Specific Immunity. Front. Immunol. 2015, 6, 603. [CrossRef] [PubMed]

81. Phillipson, M.; Heit, B.; Colarusso, P.; Liu, L.; Ballantyne, C.M.; Kubes, P. Intraluminal crawling of neutrophils to emigration sites: A molecularly distinct process from adhesion in the recruitment cascade. J. Exp. Med. 2006, 2032, 569-575.

82. Auffray, C.; Fogg, D.; Garfa, M.; Elain, G.; Join-Lambert, O.; Kayal, S.; Sarnacki, S.; Cumano, A.; Lauvau, G.; Geissmann, F. Monitoring of blood vessels and tissues by a population of monocytes with patrolling behavior. Science 2007, 3176, 66-70. [CrossRef] [PubMed]

83. Sumagin, R.; Prizant, H.; Lomakina, E.; Waugh, R.E.; Sarelius, I.H. LFA-1 and Mac-1 define characteristically different intralumenal crawling and emigration patterns for monocytes and neutrophils in situ. J. Immunol. 2010, 1857, 057-066. [CrossRef] [PubMed]

84. Carman, C.V.; Springer, T.A. A transmigratory cup in leukocyte diapedesis both through individual vascular endothelial cells and between them. J. Cell Biol. 2004, 1673, 77-88. [CrossRef] 
85. Carman, C.V.; Jun, C.D.; Salas, A.; Springer, T.A. Endothelial cells proactively form microvilli-like membrane projections upon intercellular adhesion molecule 1 engagement of leukocyte LFA-1. J. Immunol. 2003, 1716, 135-144. [CrossRef]

86. Barreiro, O.; Yanez-Mo, M.; Serrador, J.M.; Montoya, M.C.; Vicente-Manzanares, M.; Tejedor, R.; Furthmayr, H.; Sanchez-Madrid, F. Dynamic interaction of VCAM-1 and ICAM-1 with moesin and ezrin in a novel endothelial docking structure for adherent leukocytes. J. Cell Biol. 2002, 1571, 233-245. [CrossRef]

87. Van Buul, J.D.; Allingham, M.J.; Samson, T.; Meller, J.; Boulter, E.; García-Mata, R.; Burridge, K. RhoG regulates endothelial apical cup assembly downstream from ICAM1 engagement and is involved in leukocyte trans-endothelial migration. J. Cell Biol. 2007, 1781, 279-293. [CrossRef]

88. Van Rijssel, J.; Kroon, J.; Hoogenboezem, M.; van Alphen, F.P.; de Jong, R.J.; Kostadinova, E.; Geerts, D.; Hordijk, P.L.; van Buul, J.D. The Rho-guanine nucleotide exchange factor Trio controls leukocyte transendothelial migration by promoting docking structure formation. Mol. Biol. Cell 2012, 232, 831-844. [CrossRef]

89. Woodfin, A.; Voisin, M.B.; Beyrau, M.; Colom, B.; Caille, D.; Diapouli, F.M.; Nash, G.B.; Chavakis, T.; Albelda, S.M.; Rainger, G.E.; et al. The junctional adhesion molecule JAM-C regulates polarized transendothelial migration of neutrophils in vivo. Nat. Immunol. 2011, 127, 61-69. [CrossRef]

90. Ostermann, G.; Weber, K.S.; Zernecke, A.; Schröder, A.; Weber, C. JAM-1 is a ligand of the beta integrin LFA-1 involved in transendothelial migration of leukocytes. Nat. Immunol. 2002, 31, 51-58.

91. Babinska, A.; Azari, B.M.; Salifu, M.O.; Liu, R.; Jiang, X.C.; Sobocka, M.B.; Boo, D.; Al Khoury, G.; Deitch, J.S.; Marmur, J.D.; et al. The F11 receptor (F11R/JAM-A) in atherothrombosis: Overexpression of F11R in atherosclerotic plaques. Thromb. Haemost. 2007, 972, 72-81. [CrossRef]

92. Chavakis, T.; Keiper, T.; Matz-Westphal, R.; Hersemeyer, K.; Sachs, U.J.; Nawroth, P.P.; Preissner, K.T.; Santoso, S. The junctional adhesion molecule-C promotes neutrophil transendothelial migration in vitro and in vivo. J. Biol. Chem. 2004, 2795, 5602-5608.

93. Cera, M.R.; Fabbri, M.; Molendini, C.; Corada, M.; Orsenigo, F.; Rehberg, M.; Reichel, C.A.; Krombach, F.; Pardi, R.; Dejana, E. JAM-A promotes neutrophil chemotaxis by controlling integrin internalization and recycling. J. Cell Sci. 2009, 122 Pt 2, $268-277$. [CrossRef]

94. Ferrero, E.; Ferrero, M.E.; Pardi, R.; Zocchi, M.R. The platelet endothelial cell adhesion molecule-1 (PECAM1) contributes to endothelial barrier function. FEBS Lett. 1995, 3743, 23-26.

95. Marelli-Berg, F.M.; Clement, M.; Mauro, C.; Caligiuri, G. An immunologist's guide to CD31 function in T-cells. J. Cell Sci. 2013, 126 Pt 11, 2343-2352. [CrossRef]

96. Tada, Y.; Koarada, S.; Morito, F.; Ushiyama, O.; Haruta, Y.; Kanegae, F.; Ohta, A.; Ho, A.; Mak, T.W.; Nagasawa, K. Acceleration of the onset of collagen-induced arthritis by a deficiency of platelet endothelial cell adhesion molecule 1. Arthritis Rheum. 2003, 483, 280-290. [CrossRef]

97. Wong, M.X.; Hayball, J.D.; Hogarth, P.M.; Jackson, D.E. The inhibitory co-receptor.; PECAM-1 provides a protective effect in suppression of collagen-induced arthritis. J. Clin. Immunol. 2005, 251, 9-28. [CrossRef]

98. Graesser, D.; Solowiej, A.; Bruckner, M.; Osterweil, E.; Juedes, A.; Davis, S.; Rudlle, N.H.; Engelhardt, B.; Madri, J.A. Altered vascular permeability and early onset of experimental autoimmune encephalomyelitis in PECAM-1-deficient mice. J. Clin. Investig. 2002, 1093, 83-92. [CrossRef]

99. Lou, O.; Alcaide, P.; Luscinskas, F.W.; Muller, W.A. CD99 is a key mediator of the transendothelial migration of neutrophils. J. Immunol. 2007, 1781, 136-143. [CrossRef]

100. Schenkel, A.R.; Mamdouh, Z.; Chen, X.; Liebman, R.M.; Muller, W.A. CD99 plays a major role in the migration of monocytes through endothelial junctions. Nat. Immunol. 2002, 31, 43-50. [CrossRef]

101. Woodfin, A.; Voisin, M.B.; Imhof, B.A.; Dejana, E.; Engelhardt, B.; Nourshargh, S. Endothelial cell activation leads to neutrophil transmigration as supported by the sequential roles of ICAM-2.; JAM-A.; and PECAM-1. Blood 2009, 1136, 246-257. [CrossRef]

102. Broermann, A.; Winderlich, M.; Block, H.; Frye, M.; Rossaint, J.; Zarbock, A.; Cagna, G.; Linnepe, R.; Schulte, D.; Nottebaum, A.F.; et al. Dissociation of VE-PTP from VE-cadherin is required for leukocyte extravasation and for VEGF-induced vascular permeability in vivo. J. Exp. Med. 2011, 2082, 393-401.

103. Nottebaum, A.F.; Cagna, G.; Winderlich, M.; Gamp, A.C.; Linnepe, R.; Polaschegg, C.; Filippova, K.; Lyck, R.; Engelhardt, B.; Kamenyeva, O.; et al. VE-PTP maintains the endothelial barrier via plakoglobin and becomes dissociated from VE-cadherin by leukocytes and by VEGF. J. Exp. Med. 2008, 2052, 929-945. [CrossRef] [PubMed]

104. Thompson, R.D.; Noble, K.E.; Larbi, K.Y.; Dewar, A.; Duncan, G.S.; Mak, T.W.; Nourshargh, S. Platelet-endothelial cell adhesion molecule-1 (PECAM-1)-deficient mice demonstrate a transient and cytokine-specific role for PECAM-1 in leukocyte migration through the perivascular basement membrane. Blood 2001, 971, 854-860. [CrossRef] [PubMed]

105. Hoshi, O.; Ushiki, T. Neutrophil extravasation in rat mesenteric venules induced by the chemotactic peptide N-formyl-methionylluecylphenylalanine (fMLP).; with special attention to a barrier function of the vascular basal lamina for neutrophil migration. Arch. Histol. Cytol. 2004, 671, 7-14.

106. Wu, C.; Ivars, F.; Anderson, P.; Hallmann, R.; Vestweber, D.; Nilsson, P.; Robenek, H.; Tryggvason, K.; Song, J.; Korpos, E.; et al. Endothelial basement membrane laminin $\alpha 5$ selectively inhibits T lymphocyte extravasation into the brain. Nat. Med. 2009, 155, 19-27. [CrossRef] [PubMed] 
107. Sixt, M.; Engelhardt, B.; Pausch, F.; Hallmann, R.; Wendler, O.; Sorokin, L.M. Endothelial Cell Laminin Isoforms.; Laminins 8 and 10.; Play Decisive Roles in T Cell Recruitment across the Blood-Brain Barrier in Experimental Autoimmune Encephalomyelitis. J. Cell Biol. 2001, 1539, 33-46. [CrossRef]

108. Wang, S.; Voisin, M.B.; Larbi, K.Y.; Dangerfield, J.; Scheiermann, C.; Tran, M.; Maxwell, P.H.; Sorokin, L.; Nourshargh, S. Venular basement membranes contain specific matrix protein low expression regions that act as exit points for emigrating neutrophils. $J$. Exp. Med. 2006, 2031, 519-532.

109. Song, J.; Zhang, X.; Buscher, K.; Wang, Y.; Wang, H.; Di Russo, J.; Li, L.; Lutke-Enking, S.; Zarbock, A.; Stadtmann, A.; et al. Endothelial Basement Membrane Laminin 511 Contributes to Endothelial Junctional Tightness and Thereby Inhibits Leukocyte Transmigration. Cell Rep. 2017, 181, 256-269. [CrossRef]

110. Pruessmeyer, J.; Hess, F.M.; Alert, H.; Groth, E.; Pasqualon, T.; Schwarz, N.; Nyamoya, S.; Kollert, J.; van der Vorst, E.; Donners, M. Leukocytes require ADAM10 but not ADAM17 for their migration and inflammatory recruitment into the alveolar space. Blood 2014, 1234, 077-088. [CrossRef]

111. Morsing, S.K.H.; Rademakers, T.; Brouns, S.L.N.; Stalborch, A.D.V.; Donners, M.; van Buul, J.D. ADAM10-Mediated Cleavage of ICAM-1 Is Involved in Neutrophil Transendothelial Migration. Cells 2021, 10, 232. [CrossRef]

112. Kalucka, J.; de Rooij, L.; Goveia, J.; Rohlenova, K.; Dumas, S.J.; Meta, E.; Conchinha, N.V.; Taverna, F.; Teuwen, L.A.; Veys, K.; et al. Single-Cell Transcriptome Atlas of Murine Endothelial Cells. Cell 2020, 1807, 64-79.e20. [CrossRef]

113. Maas, S.L.; Soehnlein, O.; Viola, J.R. Organ-Specific Mechanisms of Transendothelial Neutrophil Migration in the Lung, Liver, Kidney, and Aorta. Front. Immunol. 2018, 9, 2739. [CrossRef] [PubMed]

114. Virmani, R.; Kolodgie, F.D.; Burke, A.P.; Farb, A.; Schwartz, S.M. Lessons from Sudden Coronary Death. Arterioscler. Thromb. Vasc. Biol. 2000, 201, 262-275. [CrossRef] [PubMed]

115. Parthasarathy, S.; Wieland, E.; Steinberg, D. A role for endothelial cell lipoxygenase in the oxidative modification of low density lipoprotein. Proc. Natl. Acad. Sci. USA 1989, 861, 046-050. [CrossRef]

116. Hartley, A.; Haskard, D.; Khamis, R. Oxidized LDL and anti-oxidized LDL antibodies in atherosclerosis-Novel insights and future directions in diagnosis and therapy. Trends Cardiovasc. Med. 2019, 292, 2-6. [CrossRef]

117. Maher, B.M.; Dhonnchu, T.N.; Burke, J.P.; Soo, A.; Wood, A.E.; Watson, R.W.G. Statins alter neutrophil migration by modulating cellular Rho activity—a potential mechanism for statins-mediated pleotropic effects? J. Leukoc. Biol. 2009, 851, 86-93. [CrossRef]

118. Park, J.G.; Ryu, S.Y.; Jung, I.H.; Lee, Y.H.; Kang, K.J.; Lee, M.R.; Lee, M.N.; Sohn, S.K.; Lee, J.H.; Lee, H.; et al. Evaluation of VCAM-1 antibodies as therapeutic agent for atherosclerosis in apolipoprotein E-deficient mice. Atherosclerosis 2013, 2263, 56-63. [CrossRef] [PubMed]

119. Cybulsky, M.I.; Iiyama, K.; Li, H.; Zhu, S.; Chen, M.; Iiyama, M.; Davis, V.; Gutierrez-Ramos, J.C.; Connelly, P.W.; Milstone, D.S. A major role for VCAM-1, but not ICAM-1, in early atherosclerosis. J. Clin. Investig. 2001, 1071, 255-262. [CrossRef] [PubMed]

120. Kitagawa, K.; Matsumoto, M.; Sasaki, T.; Hashimoto, H.; Kuwabara, K.; Ohtsuki, T.; Hori, M. Involvement of ICAM-1 in the progression of atherosclerosis in APOE-knockout mice. Atherosclerosis 2002, 1603, 05-10. [CrossRef]

121. Samson, T.; van Buul, J.D.; Kroon, J.; Welch, C.; Bakker, E.N.; Matlung, H.L.; van den Berg, T.K.; Sharek, L.; Doerschuk, C.; Hahn, K.; et al. The guanine-nucleotide exchange factor SGEF plays a crucial role in the formation of atherosclerosis. PLoS ONE 2013, 8 , e55202. [CrossRef] [PubMed]

122. Dong, Z.M.; Chapman, S.M.; Brown, A.A.; Frenette, P.S.; Hynes, R.O.; Wagner, D.D. The combined role of P- and E-selectins in atherosclerosis. J. Clin. Investig. 1998, 1021, 45-52. [CrossRef]

123. Gareus, R.; Kotsaki, E.; Xanthoulea, S.; van der Made, I.; Gijbels, M.J.; Kardakaris, R.; Polykratis, A.; Kollias, G.; de Winther, M.P.; Pasparakis, M.; et al. Endothelial cell-specific NF-kappaB inhibition protects mice from atherosclerosis. Cell Metab. 2008, 83, 72-83.

124. Beldman, T.J.; Malinova, T.S.; Desclos, E.; Grootemaat, A.E.; Misiak, A.L.S.; van der Velden, S.; van Roomen, C.; Beckers, L.; van Veen, H.A.; Krawczyk, P.M.; et al. Nanoparticle-Aided Characterization of Arterial Endothelial Architecture during Atherosclerosis Progression and Metabolic Therapy. ACS Nano 2019, 131, 3759-3774. [CrossRef] [PubMed]

125. Song, Y.; Li, Q.; Long, L.; Zhang, N.; Liu, Y. Asn563Ser polymorphism of CD31/PECAM-1 is associated with atherosclerotic cerebral infarction in a southern Han population. Neuropsychiatr. Dis. Treat. 2015, 111, 5-20.

126. Elrayess, M.A.; Webb, K.E.; Bellingan, G.J.; Whittall, R.A.; Kabir, J.; Hawe, E.; Syvanne, M.; Taskinen, M.R.; Frick, M.H.; Nieminen, M.S.; et al. R643G polymorphism in PECAM-1 influences transendothelial migration of monocytes and is associated with progression of CHD and CHD events. Atherosclerosis 2004, 1771, 27-35. [CrossRef] [PubMed]

127. Harrison, M.; Smith, E.; Ross, E.; Krams, R.; Segers, D.; Buckley, C.D.; Nash, G.B.; Rainger, G.E. The Role of Platelet-Endothelial Cell Adhesion Molecule-1 in Atheroma Formation Varies Depending on the Site-Specific Hemodynamic Environment. Arterioscler. Thromb. Vasc. Biol. 2013, 336, 94-701. [CrossRef] [PubMed]

128. Harry, B.L.; Sanders, J.M.; Feaver, R.E.; Lansey, M.; Deem, T.L.; Zarbock, A.; Bruce, A.C.; Pryor, A.W.; Gelfand, B.D.; Balckman, B.R.; et al. Endothelial cell PECAM-1 promotes atherosclerotic lesions in areas of disturbed flow in ApoE-deficient mice. Arterioscler. Thromb. Vasc. Biol. 2008, 282, 003-008. [CrossRef]

129. Goel, R.; Schrank, B.R.; Arora, S.; Boylan, B.; Fleming, B.; Miura, H.; Newman, P.J.; Molthen, R.C.; Newman, D.K. Site-Specific Effects of PECAM-1 on Atherosclerosis in LDL Receptor-Deficient Mice. Arterioscler. Thromb. Vasc. Biol. 2008, 281, 996-2002. [CrossRef] 
130. Fornasa, G.; Groyer, E.; Clement, M.; Dimitrov, J.; Compain, C.; Gaston, A.T.; Varthaman, A.; Khallou-Laschet, J.; Newman, D.K.; Graff-Dubois, S.; et al. TCR stimulation drives cleavage and shedding of the ITIM receptor CD31. J. Immunol. 2010, 1845, 485-492. [CrossRef]

131. Caligiuri, G.; Rossignol, P.; Julia, P.; Groyer, E.; Mouradian, D.; Urbain, D.; Misra, N.; Ollivier, V.; Sapoval, M.; Boutouyrie, P.; et al. Reduced immunoregulatory CD31+ T cells in patients with atherosclerotic abdominal aortic aneurysm. Arterioscler. Thromb. Vasc. Biol. 2006, 266, 18-23. [CrossRef]

132. Groyer, E.; Nicoletti, A.; Ait-Oufella, H.; Khallou-Laschet, J.; Varthaman, A.; Gaston, A.T.; Thaunat, O.; Kaveri, S.V.; Blatny, R.; Stockinger, H.; et al. Atheroprotective effect of CD31 receptor globulin through enrichment of circulating regulatory T-cells. J. Am. Coll. Cardiol. 2007, 503, 44-50. [CrossRef] [PubMed]

133. Ait-Oufella, H.; Salomon, B.L.; Potteaux, S.; Robertson, A.K.; Gourdy, P.; Zoll, J.; Merval, R.; Esposito, B.; Cohen, J.L.; Fisson, S.; et al. Natural regulatory T cells control the development of atherosclerosis in mice. Nat. Med. 2006, 121, 78-80. [CrossRef]

134. De Jong, A.; de Jong, R.C.M.; Peters, E.A.; Arens, R.; Jukema, J.W.; de Vries, M.R.; Quax, P.H.A. P300/CBP Associated Factor (PCAF) Deficiency Enhances Diet-Induced Atherosclerosis in ApoE3*Leiden Mice via Systemic Inhibition of Regulatory T Cells. Front. Cardiovasc. Med. 2021, 7, 604821. [CrossRef]

135. Klingenberg, R.; Gerdes, N.; Badeau, R.M.; Gisterå, A.; Strodthoff, D.; Ketelhuth, D.F.; Lundberg, A.M.; Rudling, M.; Nilsson, S.K.; Olivecrona, G.; et al. Depletion of FOXP3+ regulatory T cells promotes hypercholesterolemia and atherosclerosis. J. Clin. Investig. 2013, 1231, 323-334. [CrossRef] [PubMed]

136. Saigusa, R.; Winkels, H.; Ley, K. T cell subsets and functions in atherosclerosis. Nat. Rev. Cardiol. 2020, 173, 87-401. [CrossRef]

137. Simons, K.H.; de Jong, A.; Jukema, J.W.; de Vries, M.R.; Arens, R.; Quax, P.H.A. T cell co-stimulation and co-inhibition in cardiovascular disease: A double-edged sword. Nat. Rev. Cardiol. 2019, 163, 25-43. [CrossRef]

138. Cochain, C.; Chaudhari, S.M.; Koch, M.; Wiendl, H.; Eckstein, H.H.; Zernecke, A. Programmed cell death-1 deficiency exacerbates $\mathrm{T}$ cell activation and atherogenesis despite expansion of regulatory $\mathrm{T}$ cells in atherosclerosis-prone mice. PLoS ONE 2014, 9 , e93280. [CrossRef]

139. Van Gils, J.M.; Zwaginga, J.J.; Hordijk, P.L. Molecular and functional interactions among monocytes.; platelets.; and endothelial cells and their relevance for cardiovascular diseases. J. Leukoc. Biol. 2009, 851, 95-204. [CrossRef] [PubMed]

140. Karshovska, E.; Zhao, Z.; Blanchet, X.; Schmitt, M.M.; Bidzhekov, K.; Soehnlein, O.; von Hundelshausen, P.; Mattheij, N.J.; Cosemans, J.M.; Megens, R.T.; et al. Hyperreactivity of junctional adhesion molecule A-deficient platelets accelerates atherosclerosis in hyperlipidemic mice. Circ. Res. 2015, 1165, 87-99. [CrossRef] [PubMed]

141. Hillgruber, C.; Pöppelmann, B.; Weishaupt, C.; Steingräber, A.K.; Wessel, F.; Berdel, W.E.; Gessner, J.E.; Ho-Tin-Noe, B.; Vestweber, D.; Goerge, T. Blocking neutrophil diapedesis prevents hemorrhage during thrombocytopenia. J. Exp. Med. 2015, 2121, 255-266.

142. Collot-Teixeira, S.; Martin, J.; McDermott-Roe, C.; Poston, R.; McGregor, J.L. CD36 and macrophages in atherosclerosis. Cardiovasc. Res. 2007, 754, 68-77.

143. Newby, A.C. Metalloproteinase Expression in Monocytes and Macrophages and its Relationship to Atherosclerotic Plaque Instability. Arterioscler. Thromb. Vasc. Biol. 2008, 282, 108-114. [CrossRef] [PubMed]

144. Parathath, S.; Mick, S.L.; Feig, J.E.; Joaquin, V.; Grauer, L.; Habiel, D.M.; Gassmann, M.; Gardner, L.B.; Fisher, E.A. Hypoxia is present in murine atherosclerotic plaques and has multiple adverse effects on macrophage lipid metabolism. Circ. Res. 2011, 1091, 141-152. [CrossRef] [PubMed]

145. Aarup, A.; Pedersen, T.X.; Junker, N.; Christoffersen, C.; Bartels, E.D.; Madsen, M.; Nielsen, C.H.; Nielsen, L.B. Hypoxia-Inducible Factor-1 $\alpha$ Expression in Macrophages Promotes Development of Atherosclerosis. Arterioscler. Thromb. Vasc. Biol. 2016, 361, 782-790. [CrossRef] [PubMed]

146. Björnheden, T.; Levin, M.; Evaldsson, M.; Wiklund, O. Evidence of Hypoxic Areas within the Arterial Wall In Vivo. Arterioscler. Thromb. Vasc. Biol. 1999, 198, 70-76. [CrossRef] [PubMed]

147. Sluimer, J.C.; Gasc, J.M.; van Wanroij, J.L.; Kisters, N.; Groeneweg, M.; Sollewijn Gelpke, M.D.; Cleutjes, J.P.; van den Akker, L.H.; Corvol, P.; Wouters, B.G.; et al. Hypoxia, hypoxia-inducible transcription factor.; and macrophages in human atherosclerotic plaques are correlated with intraplaque angiogenesis. J. Am. Coll. Cardiol. 2008, 511, 258-265. [CrossRef] [PubMed]

148. Parma, L.; Peters, H.A.B.; Baganha, F.; Sluimer, J.C.; de Vries, M.R.; Quax, P.H.A. Prolonged Hyperoxygenation Treatment Improves Vein Graft Patency and Decreases Macrophage Content in Atherosclerotic Lesions in ApoE3*Leiden Mice. Cells 2020, 9 , 336. [CrossRef]

149. Hutter, R.; Speidl, W.S.; Valdiviezo, C.; Sauter, B.; Corti, R.; Fuster, V.; Badimon, J.J. Macrophages transmit potent proangiogenic effects of oxLDL in vitro and in vivo involving HIF- $1 \alpha$ activation: A novel aspect of angiogenesis in atherosclerosis. J. Cardiovasc. Transl. Res. 2013, 65, 58-69. [CrossRef]

150. Chaudhari, S.M.; Sluimer, J.C.; Koch, M.; Theelen, T.L.; Manthey, H.D.; Busch, M.; Caballero-Franco, C.; Vogel, F.; Cochain, C.; Pelisek, J.; et al. Deficiency of HIF1 $\alpha$ in Antigen-Presenting Cells Aggravates Atherosclerosis and Type 1 T-Helper Cell Responses in Mice. Arterioscler. Thromb. Vasc. Biol. 2015, 352, 316-325. [CrossRef]

151. Herbert, S.P.; Stainier, D.Y. Molecular control of endothelial cell behaviour during blood vessel morphogenesis. Nat. Rev. Mol. Cell Biol. 2011, 125, 51-64. [CrossRef] [PubMed]

152. Gavard, J.; Gutkind, J.S. VEGF controls endothelial-cell permeability by promoting the beta-arrestin-dependent endocytosis of VE-cadherin. Nat. Cell Biol. 2006, 81, 223-234. 
153. Lampugnani, M.G.; Orsenigo, F.; Gagliani, M.C.; Tacchetti, C.; Dejana, E. Vascular endothelial cadherin controls VEGFR-2 internalization and signaling from intracellular compartments. J. Cell Biol. 2006, 1745, 93-604. [CrossRef] [PubMed]

154. Donners, M.M.; Wolfs, I.M.; Olieslagers, S.; Mohammadi-Motahhari, Z.; Tchaikovski, V.; Heeneman, S.; van Buul, J.D.; Caolo, V.; Molin, D.G.; Post, M.J.; et al. A disintegrin and metalloprotease 10 is a novel mediator of vascular endothelial growth factor-induced endothelial cell function in angiogenesis and is associated with atherosclerosis. Arterioscler. Thromb. Vasc. Biol. 2010, 302, 188-195. [CrossRef] [PubMed]

155. Hellings, W.E.; Peeters, W.; Moll, F.L.; Piers, S.R.; van Setten, J.; Van der Spek, P.J.; de Vries, J.P.; Seldenrijk, K.A.; de Bruin, P.C.; Vink, A.; et al. Composition of carotid atherosclerotic plaque is associated with cardiovascular outcome: A prognostic study. Circulation 2010, 1211, 941-950. [CrossRef]

156. Simon, M.P.; Tournaire, R.; Pouyssegur, J. The angiopoietin-2 gene of endothelial cells is up-regulated in hypoxia by a HIF binding site located in its first intron and by the central factors GATA-2 and Ets-1. J. Cell Physiol. 2008, 2178, 09-18. [CrossRef]

157. Gamble, J.R.; Drew, J.; Trezise, L.; Underwood, A.; Parsons, M.; Kasminkas, L.; Rudge, J.; Yancopoulos, G.; Vadas, M.A. Angiopoietin-1 is an antipermeability and anti-inflammatory agent in vitro and targets cell junctions. Circ. Res. 2000, 876, 03-07. [CrossRef]

158. Parma, L.; Baganha, F.; Quax, P.H.A.; de Vries, M.R. Plaque angiogenesis and intraplaque hemorrhage in atherosclerosis. Eur. J. Pharmacol. 2017, 8161, 07-15. [CrossRef]

159. Melder, R.J.; Yuan, J.; Munn, L.L.; Jain, R.K. Erythrocytes enhance lymphocyte rolling and arrest in vivo. Microvasc. Res. 2000, 593, 16-22. [CrossRef]

160. Nagy, E.; Eaton, J.W.; Jeney, V.; Soares, M.P.; Varga, Z.; Galajda, Z.; Szentmiklosi, J.; Mehes, G.; Csonka, T.; Smith, A.; et al. Red cells, hemoglobin, heme, iron, and atherogenesis. Arterioscler. Thromb. Vasc. Biol. 2010, 301, 347-353. [CrossRef]

161. Jeney, V.; Balla, G.; Balla, J. Red blood cell, hemoglobin and heme in the progression of atherosclerosis. Front. Physiol. 2014, 5, 379. [CrossRef]

162. Boyle, J.J.; Harrington, H.A.; Piper, E.; Elderfield, K.; Stark, J.; Landis, R.C.; Haskard, D.O. Coronary intraplaque hemorrhage evokes a novel atheroprotective macrophage phenotype. Am. J. Pathol. 2009, 1741, 097-108. [CrossRef] [PubMed]

163. Guo, L.; Akahori, H.; Harari, E.; Smith, S.L.; Polavarapu, R.; Karmali, V.; Otsuka, F.; Gannon, R.L.; Braumann, R.E.; Dickinson, M.H.; et al. CD163+ macrophages promote angiogenesis and vascular permeability accompanied by inflammation in atherosclerosis. J. Clin. Investig. 2018, 1281, 106-124. [CrossRef] [PubMed]

164. De Vries, M.R.; Parma, L.; Peters, H.A.B.; Schepers, A.; Hamming, J.F.; Jukema, J.W.; Goumans, M.J.T.H.; Guo, L.; Finn, A.V.; Virmani, R.; et al. Blockade of vascular endothelial growth factor receptor 2 inhibits intraplaque haemorrhage by normalization of plaque neovessels. J. Intern. Med. 2019, 2855, 9-74. [CrossRef]

165. Taqueti, V.R.; Di Carli, M.F.; Jerosch-Herold, M.; Sukhova, G.K.; Murthy, V.L.; Folco, E.J.; Kwong, R.Y.; Ozaki, C.K.; Belkin, M.; Nahrendorf, M.; et al. Increased microvascularization and vessel permeability associate with active inflammation in human atheromata. Circ. Cardiovasc. Imag. 2014, 79, 20-29. [CrossRef]

166. Oksala, N.; Levula, M.; Airla, N.; Pelto-Huikko, M.; Ortiz, R.M.; Järvinen, O.; Salenius, J.P.; Ozsait, B.; Komurcu-Bayrak, E.; Erginel-Unaltuna, N.; et al. ADAM-9, ADAM-15, and ADAM-17 are upregulated in macrophages in advanced human atherosclerotic plaques in aorta and carotid and femoral arteries-Tampere vascular study. Ann. Med. 2009, 412, 79-90. [CrossRef]

167. Satoh, M.; Ishikawa, Y.; Itoh, T.; Minami, Y.; Takahashi, Y.; Nakamura, M. The expression of TNF-alpha converting enzyme at the site of ruptured plaques in patients with acute myocardial infarction. Eur. J. Clin. Investig. 2008, 389, 7-105.

168. De Vries, M.R.; Quax, P.H. Plaque angiogenesis and its relation to inflammation and atherosclerotic plaque destabilization. Curr. Opin. Lipidol. 2016, 274, 99-506. [CrossRef]

169. Virmani, R.; Kolodgie, F.D.; Burke, A.P.; Finn, A.V.; Gold, H.K.; Tulenko, T.N.; Wrenn, S.P.; Narula, J. Atherosclerotic Plaque Progression and Vulnerability to Rupture. Arterioscle. Thromb. Vasc. Biol. 2005, 252, 054-061. [CrossRef] [PubMed]

170. Parma, L.; Peters, H.A.B.; Sluiter, T.J.; Simons, K.H.; Lazzari, P.; de Vries, M.R.; Quax, P.H.A. bFGF blockade reduces intraplaque angiogenesis and macrophage infiltration in atherosclerotic vein graft lesions in ApoE3*Leiden mice. Sci. Rep. 2020, $101,5968$. [CrossRef]

171. Van der Vorst, E.P.; Zhao, Z.; Rami, M.; Holdt, L.M.; Teupser, D.; Steffens, S.; Weber, C. Contrasting effects of myeloid and endothelial ADAM17 on atherosclerosis development. Thromb. Haemost. 2017, 1176, 44-46.

172. Members, T.F.; Montalescot, G.; Sechtem, U.; Achenbach, S.; Andreotti, F.; Arden, C.; Budaj, A.; Bugiardini, R.; Crea, F.; Cuisset, T.; et al. 2013 ESC guidelines on the management of stable coronary artery disease: The Task Force on the management of stable coronary artery disease of the European Society of Cardiology. Eur. Heart J. 2013, 342, 949-3003.

173. Randomised trial of cholesterol lowering in 4444 patients with coronary heart disease: The Scandinavian Simvastatin Survival Study (4S). Lancet 1994, 3441, 383-389.

174. Nohria, A.; Grunert, M.E.; Rikitake, Y.; Noma, K.; Prsic, A.; Ganz, P.; Liao, J.K.; Creager, M.A. Rho kinase inhibition improves endothelial function in human subjects with coronary artery disease. Circ. Res. 2006, 991, 426-432. [CrossRef]

175. Wagner, A.H.; Köhler, T.; Rückschloss, U.; Just, I.; Hecker, M. Improvement of nitric oxide-dependent vasodilatation by HMG-CoA reductase inhibitors through attenuation of endothelial superoxide anion formation. Arterioscler. Thromb. Vasc. Biol. 2000, 206, 1-9. [CrossRef] [PubMed] 
176. Weitz-Schmidt, G.; Welzenbach, K.; Brinkmann, V.; Kamata, T.; Kallen, J.; Bruns, C.; Cottens, S.; Takada, Y.; Hommel, U. Statins selectively inhibit leukocyte function antigen-1 by binding to a novel regulatory integrin site. Nat. Med. 2001, 76, 87-92. [CrossRef] [PubMed]

177. Zhu, Y.C.; Jiang, X.Z.; Bai, Q.K.; Deng, S.H.; Zhang, Y.; Zhang, Z.P.; Jiang, Q. Evaluating the Efficacy of Atorvastatin on Patients with Carotid Plaque by an Innovative Ultrasonography. J. Stroke Cerebrovasc. Dis. 2019, 288, 30-37. [CrossRef]

178. Hochman, J.S.; Phillips, W.J.; Ruggieri, D.; Ryan, S.F. The distribution of atherosclerotic lesions in the coronary arterial tree: Relation to cardiac risk factors. Am. Heart J. 1988, 116 Pt 1, 1217-1222. [CrossRef]

179. McGill, H.C.; McMahan, C.A.; Herderick, E.E.; Tracy, R.E.; Malcom, G.T.; Zieske, A.W.; Strong, J.P. Effects of Coronary Heart Disease Risk Factors on Atherosclerosis of Selected Regions of the Aorta and Right Coronary Artery. Arterioscler. Thromb. Vasc. Biol. 2000, 208, 36-45. [CrossRef]

180. Chiu, J.J.; Chien, S. Effects of disturbed flow on vascular endothelium: Pathophysiological basis and clinical perspectives. Physiol. Rev. 2011, 913, 27-87. [CrossRef] [PubMed]

181. Moossy, J. Morphology, sites and epidemiology of cerebral atherosclerosis. Res. Publ. Assoc. Res. Nerv. Ment Dis. 1966, 411, 22.

182. D'Armiento, F.P.; Bianchi, A.; de Nigris, F.; Capuzzi, D.M.; D'Armiento, M.R.; Crimi, G.; Abete, P.; Palinski, W.; Condorelli, M.; Napoli, C. Age-related effects on atherogenesis and scavenger enzymes of intracranial and extracranial arteries in men without classic risk factors for atherosclerosis. Stroke 2001, 322, 472-479. [CrossRef]

183. Ritz, K.; Denswil, N.P.; Stam, O.C.G.; Lieshout, J.J.V.; Daemenm, M.J.A.P. Cause and Mechanisms of Intracranial Atherosclerosis. Circulation 2014, 1301, 407-414. [CrossRef]

184. Napoli, C.; Paternò, R.; Faraci, F.M.; Taguchi, H.; Postiglione, A.; Heistad, D.D. Mildly Oxidized Low-Density Lipoprotein Impairs Responses of Carotid but Not Basilar Artery in Rabbits. Stroke 1997, 282, 266-272. [CrossRef]

185. De Boer, O.J.; van der Wal, A.C.; Teeling, P.; Becker, A.E. Leucocyte recruitment in rupture prone regions of lipid-rich plaques: A prominent role for neovascularization? Cardiovasc. Res. 1999, 414, 43-49. [CrossRef]

186. Sluimer, J.C.; Daemen, M.J. Novel concepts in atherogenesis: Angiogenesis and hypoxia in atherosclerosis. J. Pathol. 2009, 2187, 29. [CrossRef]

187. Steenman, M.; Espitia, O.; Maurel, B.; Guyomarch, B.; Heymann, M.F.; Pistorius, M.A.; Ory, B.; Heymann, D.; Houlgatte, R.; Goueffic, Y.; et al. Identification of genomic differences among peripheral arterial beds in atherosclerotic and healthy arteries. Sci. Rep. 2018, 83, 940. [CrossRef] [PubMed]

188. Yin, D.; Matsumura, M.; Rundback, J.; Yoho, J.A.; Witzenbichler, B.; Stone, G.W.; Mintz, G.S.; Maehara, A. Comparison of plaque morphology between peripheral and coronary artery disease (from the CLARITY and ADAPT-DES IVUS substudies). Coron. Artery Dis. 2017, 283, 69-75. [CrossRef] [PubMed]

189. Matsuo, Y.; Takumi, T.; Mathew, V.; Chung, W.Y.; Barsness, G.W.; Rihal, C.S.; Gulati, R.; McCue, E.T.; Holmes, D.R.; Eeckhout, E.; et al. Plaque characteristics and arterial remodeling in coronary and peripheral arterial systems. Atherosclerosis 2012, 2233, 65-71. [CrossRef] [PubMed]

190. Hildebrandt, H.A.; Gossl, M.; Mannheim, D.; Versari, D.; Herrmann, J.; Spendlove, D.; Bajanowski, T.; Malyar, N.M.; Erbel, R.; Lerman, L.O.; et al. Differential distribution of vasa vasorum in different vascular beds in humans. Atherosclerosis 2008, 1994, 7-54. [CrossRef] [PubMed] 